\title{
Comprehensive review of antimicrobial activities of plant flavonoids
}

\author{
Ireneusz Górniak · Rafał Bartoszewski · Jarosław Króliczewski $\mathbb{C}$
}
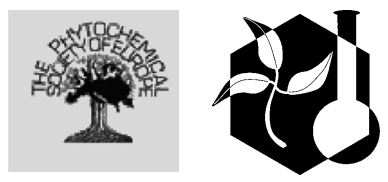

Received: 5 December 2017 / Accepted: 29 September 2018/Published online: 6 October 2018

(C) The Author(s) 2018

\begin{abstract}
Flavonoids are one of the largest classes of small molecular secondary metabolites produced in different parts of the plant. They display a wide range of pharmacological and beneficial health effects for humans, which include, among others, antioxidative activity, free radical scavenging capacity, coronary heart disease prevention and antiatherosclerotic, hepatoprotective, anti-inflammatory, and anticancer activities. Hence, flavonoids are gaining high attention from the pharmaceutical and healthcare industries. Notably, plants synthesize flavonoids in response to microbial infection, and these compounds have been found to be a potent antimicrobial agent against a wide range of pathogenic microorganisms in vitro. Antimicrobial action of flavonoids results from their various biological activities, which may not seem very specific at first. There are, however, promising antibacterial flavonoids that are able not only to selectively target bacterial cells, but also to inhibit virulence factors, as well as other forms of microbial threats, e.g. biofilm formation. Moreover, some plant flavonoids manifest
\end{abstract}

\section{Górniak}

Department of Biophysics, Faculty of Biotechnology,

University of Wroclaw, Fryderyka Joliot-Curie 14a,

50-383 Wroclaw, Poland

R. Bartoszewski · J. Króliczewski ( $\square$ )

Department of Biology and Pharmaceutical Botany,

Medical University of Gdansk, Hallera 107,

80-416 Gdansk, Poland

e-mail: jakrol@windowslive.com ability to reverse the antibiotic resistance and enhance action of the current antibiotic drugs. Hence, the development and application of flavonoid-based drugs could be a promising approach for antibiotic-resistant infections. This review aims to improve our understanding of the biological and molecular roles of plant flavonoids, focusing mostly on their antimicrobial activities.

Keywords Antibiotic resistance $\cdot$ Antibacterial mechanism $\cdot$ Medicinal plants $\cdot$ Nutraceuticals . Secondary metabolites
Abbreviations
AHL $\quad N$-acyl homo-serine lactones
AGs Aminoglycoside antibiotics
CFU Colony-forming units
EC Epicatechin
ECG Epicatechin gallate
EGCG Epigallocatechin gallate
EPI Efflux pump inhibitors
FAS-I Fatty acid synthase type I
FAS-II Fatty acid synthase type II
FICI Fractional inhibitory concentration index
MBC Minimum bactericidal concentration
MDR Multidrug resistant strains
MIC Minimum inhibitory concentration
MRSA Methicillin-resistant Staphylococcus aureus
MSSA Methicillin-sensitive Staphylococcus aureus 
PMF Proton-motive force

ROS Reactive oxygen species

QS Quorum sensing

\section{Introduction}

Pathogenic microorganisms have been a danger to the human race since its genesis, being a major cause of human morbidity and mortality. Until the discovery of the first true antibiotic_-penicillin-in 1928 and sulfa drugs in the 1930s, besides the toxic arsenic, the only means of fighting infectious diseases were plant extracts of different sorts, though their usage yielded various results (Dar et al. 2016; Saleem et al. 2010; van Miert 1994).

Although, for the last 60 years, antibiotics played a major role in the treatment of infectious diseases caused by bacteria and fungi, the occurrence of dangerous and antibiotic-resistant bacteria have been observed to increase in frequency over the past several decades. Drug resistance can be executed by multiple mechanisms; hence overcoming such problem is not an easy task (Saleem et al. 2010). Reasons for the emerging antibiotic resistance include the irresponsible, unfit or too common use of antibiotics in fields, such as medicine, veterinary, and especially in agriculture (Pisteli and Giorgi 2012). Moreover, the pipeline of new antimicrobial agents is running dry since the $70 \mathrm{~s}$, while the number of drug-resistant bacteria has increased (Croft et al. 2007; Shah 2005), leading some to claim that a post-antibiotic era is eminent (Appelbaum 2012). Hence, there is a pressing need for finding new antimicrobial drugs.

The use of plants as medicines has a long history in the treatment of various diseases and to date, $\sim 100,000$ plant species have been tested for their medicinal use (Schmidt et al. 2012; Veeresham 2012). In 2007 WHO estimated that $25 \%$ of available drugs are derived from plants used in folk medicine (Cushnie et al. 2008). Besides the long-established clinical use, the plant-derived compounds display good tolerance and acceptance among patients and seem like a credible source of antimicrobial compounds. Among 109 new antibacterial drugs, approved in the period 1981-2006, 69\% originated from natural products (Newman 2008). One of the major groups of phytochemicals that has been studied extensively for their antimicrobial properties are flavonoids (Pisteli and Giorgi 2012). Flavonoids, being mostly plants pigments, belong to a wide class of chemical compounds (over 6000 different hydroxylated polyphenols) that carry out important functions in plants, including attracting insects that pollinate, combating environmental stresses such as microbial infection, and regulating the cell growth (Falcone Ferreyra et al. 2012; Kumar and Pandey 2013). Fruits and vegetables are the main dietary sources of flavonoids for humans.

The flavonoids are known for their antioxidant, anti-inflammatory, antiallergic, anticancer, antiviral, and antifungal properties (Harborne and Williams 2000; Havsteen 1983; Havsteen 2002). However, since plants synthetize flavonoids in response to microbial infection (Perumal Samy and Gopalakrishnakone 2010), there is a growing interest about the antibacterial properties of flavonoids and their application in the therapy for human diseases.

The therapeutic use of flavonoids is supported by the successful use of preparations containing these physiologically active constituents in folk medicine. For example, Tagetes minuta containing quercetagetin-7-arabinzylgalactoside was widely used in the Argentinean folk medicine for the treatment of various infectious diseases (Tereschuk et al. 1997). Flower extracts of Retama raetam (Forssk) containing, among others, licoflavone $\mathrm{C}$ and derrone displayed antibacterial activity against Gram-positive and Gram-negative bacteria (Edziri et al. 2012; Hayet et al. 2008). Tripleurospermum disciforme (known by the common name Mayweed), used as a disinfectant and in the treatment of some diseases in folk medicine of Iran, contains abundance of flavonoids, including apigenin, kaempferol, luteolin, quercetin, and their respective glycosides (Tofighi et al. 2015).

In this review, we have summarized the general information about flavonoid structure, basic properties, and their occurrence and discuss their scope of antimicrobial activity as a possible replacement of conventional antibiotics. Moreover, we have analyzed the recently reported flavonoid compounds, which display potent antimicrobial activities, and have provided examples of flavonoids that manifest synergistic and additive effects upon combining with other antibiotic drugs. 


\section{Flavonoids structure and nomenclature}

Flavonoids are a class of natural phenolic compounds that include a $\mathrm{C}_{6}-\mathrm{C}_{3}-\mathrm{C}_{6}$ carbon framework (phenyl benzopyran). The basic flavonoid structure consists of a 2-phenyl-benzo- $\gamma$-pyrane nucleus comprising two benzene Rings A and B linked through a heterocyclic pyran or pyrone Ring C. Depending on the level of unsaturation and oxidation, flavonoids can be grouped into various subclasses, such as flavones (Fig. 1), isoflavones (Fig. 2), flavonols (Fig. 3), flavanols (otherwise known as catechins, Fig. 4), flavanones (Fig. 5), flavanonols (Fig. 6), chalcones and dihydrochalcones (Fig. 7), aurones and anthocyanidins (Fig. 8), and others that are not noted for their antimicrobial activities (Falcone Ferreyra et al. 2012) and are not discussed in this paper.

It should not be disregarded, that huge structural diversity and wide biological activity of flavonoids comes from their frequent modifications (Chen et al. 2018). Flavonoid glycosides, as well as their prenylated, geranylated, methoxylated and hydroxylated derivatives vary in structure and mode of antibacterial action (Cushnie and Lamb 2011). The chemical structures of flavonoids discussed here are presented in Figs. 1, 2, 3, 4, 5, 7 and 8 (where these compounds were grouped accordingly to their chemical classes).

Currently, three approaches are being used in naming flavonoid compounds, which may cause some confusion, considering the huge number of new flavonoids being isolated. The most common approach is using the trivial name that relates to the subclass to which the compound belongs to, or the plant from which it was first extracted from. Another approach is using the semi-systematic name, where the core of the name comes from the subclass, for example, $3,5,7,3^{\prime}, 4^{\prime}$-pentahydroxyflavone. The third method is naming the flavonoids by their systematic chemical names, for example, 3,4-dihydro-2-phenyl-2H-1-benzopyran (flavan). Although this method is overcomplicated in case of common flavonoids, it is the most precise approach, and thus superior to other naming approaches, especially when naming novel compounds (Cushnie and Lamb 2005). One of the recommendations for the flavonoid nomenclature was prepared by the IUPAC (Rauter 2013). These recommendations establish rules for the general nomenclature of flavonoids, providing examples of acceptable trivial names, and names derived from trivial names, along with semi-systematic and fully systematic names that follow the published IUPAC recommendations (International Union of Pure and Applied Chemistry 1993). However, in this paper, we decided to use the most common approaches (trivial and semi-systematic for well-known and novel flavonoids, respectively), as we feel that they are sufficient for the purposes of this review.

\section{Physiological roles of plant flavonoids}

Flavonoids are present in most of the plants, generally in all of their organs. As the most abundant secondary plant metabolites, their quantitative distribution varies from organ to organ or even plant to plant, depending on the environment. The composition of flavonoids varies, depending on the plant's water and nutrient availability, intensity of sunlight, type of soil, and the age of the plant (Havsteen 2002). Nevertheless, plants of the same taxon tend to produce a similar set of flavonoids, suggesting that genetic predispositions of plants are dominant (Havsteen 2002; Nicotra et al. 2010).

Those compounds fulfill variety of functions in plant organs. Anthocyanins along with other flavonoids color flowers and fruits, which attracts pollinators and seed dispersers (reviewed in Narbona et al. 2014; Schiestl and Johnson 2013). In vegetative organs, anthocyanins and other non-pigmented flavonoids, such as flavones and flavonols, may provide some protective functions against many biotic and abiotic stressors like herbivores, UV radiation, cold, heat, drought, and salinity (Anderson et al. 2013; Falcone Ferreyra et al. 2012; Hatier and Gould 2009). Moreover, flavonoids take part in energy transfers, regulation of photosynthesis and morphogenesis, regulation of growth factors, and sex determination (Harborne and Baxter 1999).

More importantly, there are reports suggesting that flavonoids are important antimicrobials in plant life. To arrest the spread of pathogens, plants possess an innate immunity that involves different layers of defense responses and some of these defenses include biosynthesis of flavonoids (Piasecka et al. 2015). Beck and Stengel (2016) found that flavonoids are mostly concentrated along the vascular strands of leaves, rather than being evenly distributed throughout the leaf tissue. This is due to the need for the quick 


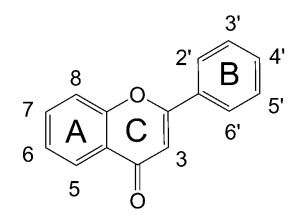

flavone subclass backbone<smiles>Nc1ccc2oc(-c3ccccc3)cc(=O)c2c1</smiles>

6-aminoflavone (1)<smiles>O=c1cc(-c2ccc(O)c(O)c2)oc2cc(O)c(O)c(O)c12</smiles><smiles>O=c1c(O)c(-c2ccc(O)c(O)c2)oc2cc(O)c(O)cc12</smiles>

6-hydroxyflavone (2) 5,6,7,4',5'-pentahydroxyflavone (3) 3,6,7,3',4'-pentahydroxyflavone (4)<smiles></smiles>

5-hydroxy-4',7-dimethoxyflavone (5) 7,4'-dimethylapigenin (6) 6-prenylapigenin (7) 4',5',5-trihydroxy-6,7-dimethoxyflavone (8)<smiles>COc1ccc(-c2cc(=O)c3c(O)cc(O)cc3o2)cc1</smiles>

$\operatorname{acacetin}(9)$<smiles>COc1ccc(-c2cc(=O)c3c(O)cc(O)cc3o2)cc1O</smiles>

diosmetin (13)<smiles>O=c1cc(-c2ccc(O)cc2)oc2cc(O)cc(O)c12</smiles>

apigenin (10)<smiles>O=c1cc(-c2ccccc2)oc2cc(O)c(O)c(O)c12</smiles>

baicalein (11)<smiles>O=c1cc(-c2ccccc2)oc2cc(O)cc(O)c12</smiles>

chrysin (12)<smiles>O=c1cc(-c2ccc(O)c(O)c2)oc2cc(O)cc(O)c12</smiles>

luteolin (15)<smiles>COc1ccc(-c2cc(=O)c3c(OC)c(OC)c(OC)c(OC)c3o2)cc1OC</smiles>

nobiletin (16)<smiles>O=c1cc(-c2ccc(O)cc2)oc2cc(O)c([C@H]3O[C@@H](O)[C@@H](O)[C@H](O)[C@H]3O)c(O)c12</smiles>

isovitexin (apigenin-6-C-glycoside) (14)<smiles>O=c1c(O)c(-c2cc(O)c(O)c(O)c2)oc2cc(O)ccc12</smiles>

robinetin (17)<smiles>COc1c(O)c(OC)c2oc(-c3ccc(O)cc3)c(OC)c(=O)c2c1O</smiles>

sarothrin (18)<smiles>COc1ccc(-c2cc(=O)c3c(OC)c(OC)c(OC)c(OC)c3o2)cc1</smiles>

tangeritin (19)

Fig. 1 Chemical structures of flavones

distribution of flavonoids via vascular strands, which shows the important roles of flavonoids in physiological regulation, chemical messaging, deterring of the feeding, and possibly pathogen attack response. In fact, flavonoids serve as phytoalexins categorized as compounds that protect plants from different types of 


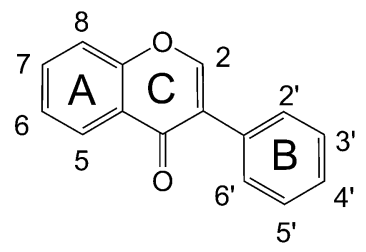

isoflavone subclass backbone<smiles>COc1ccc(-c2coc3cc(O)cc(O)c3c2=O)cc1</smiles>

biochanin A (20)<smiles>O=c1c(-c2ccc(O)cc2)coc2cc(O)cc(O)c12</smiles>

genistein (22)<smiles>O=c1c(-c2ccc(O)cc2)coc2cc(O)ccc12</smiles>

daidzein (21)<smiles>CC(C)=CCc1cc(-c2coc3c(CC=C(C)C)c(O)cc(O)c3c2=O)ccc1O</smiles>

isolupalbigenin (23)

Fig. 2 Chemical structures of isoflavones

pathogens (Cowan 1999). For example, a flavanone sakuranetin was found in abundance in rice, where it combats various pathogens, both bacterial and fungal (Cho and Lee 2015). Moreover, many classes of flavonoids have been identified as allelochemicals that inhibit the growth of microorganisms around the plant. Examples of those include chalcones, dihydrochalcones, flavonols, flavanols, flavanones and isoflavonoids (Beck and Stengel 2016; Iwashina 2003).

\section{Mechanisms of antimicrobial action by flavonoids}

To date, many flavonoids were characterized by the antibacterial activities against plant pathogens, which could be effectively applied to fight human pathogens. Moreover, the antibacterial activities of many plantderived flavonoids use different mechanisms than those of conventional drugs, and thus could be of importance in the enhancement of antibacterial therapy (Pandey and Kumar 2013).
Membrane disruption

The bacterial plasma membrane is responsible for osmoregulation, respiration and transport processes, biosynthesis and cross-linking of peptidoglycan, as well as biosynthesis of lipids. For performing all of these functions, membrane integrity is a prerequisite, and its disruption can directly or indirectly cause metabolic dysfunction and finally lead to bacterial death (Hartmann et al. 2010). To date, flavonoids, especially catechins, have been widely studied for their antimicrobial properties in both Gram-positive and Gram-negative bacteria. The interactions of flavonoids with lipid bilayers involve two mechanisms (Tsuchiya 2015). The first is associated with the partition of the more non-polar compounds in the hydrophobic interior of the membrane, while the second one includes the formation of hydrogen bonds between the polar head groups of lipids and the more hydrophilic flavonoids at the membrane interface. Moreover, nonspecific interactions of flavonoids with 


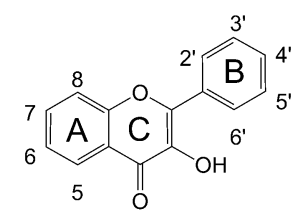

flavonol subclass backbone<smiles>O=c1c(O)c(-c2ccc(O)c(O)c2)oc2cc(O)ccc12</smiles>

fisetin (24)<smiles>O=c1c(O)c(-c2ccccc2)oc2cc(O)cc(O)c12</smiles>

galangin (25)<smiles>O=c1c(O)c(-c2ccc(O)cc2O)oc2cc(O)cc(O)c12</smiles>

morin (26)<smiles>O=c1c(O)c(-c2cc(O)c(O)c(O)c2)oc2cc(O)cc(O)c12</smiles>

myricetin (27)<smiles>O=c1c(O)c(-c2ccc(O)cc2)oc2cc(O)cc(O)c12</smiles>

kaempferol (28)

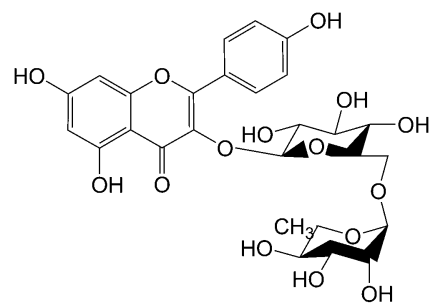

kaempferol-3-O-rutinoside (29)<smiles>COc1ccc(-c2oc3cc(O)cc(O)c3c(=O)c2O)cc1</smiles>

kaempferide (30)<smiles>COc1ccc(-c2oc3cc(O)cc(O)c3c(=O)c2O[C@H]2O[C@H](CO)[C@@H](O)[C@H](O)[C@H](O)[C@H]2O)cc1</smiles>

kaempferide-3-O-glucoside (31)

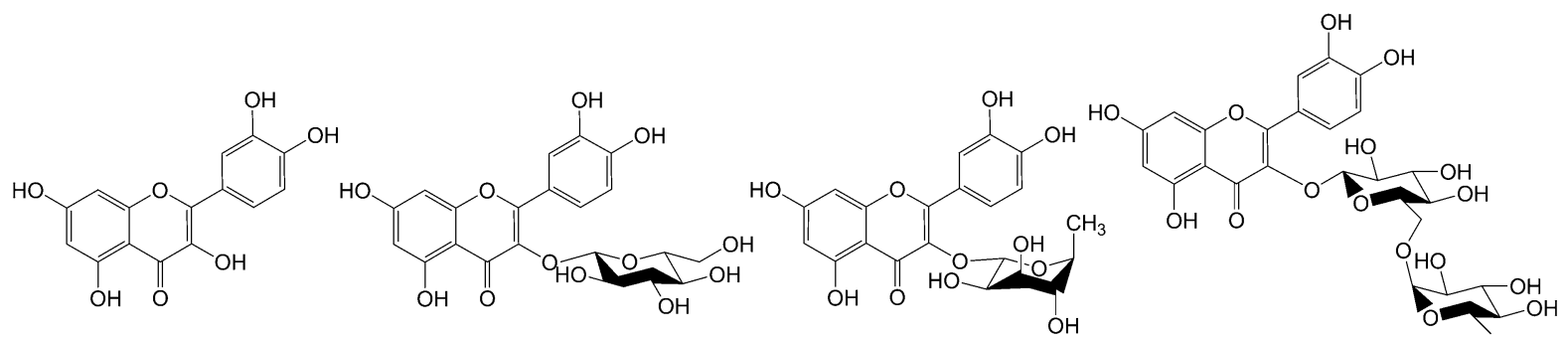

quercetin (32)

quercetin-3-O-glucoside (isoquercetin) (33) quercetin-3- $O$-rhamnoside (quercitrin) (34) quercetin-3- $O$-rhamnoglucoside (rutin) (35)

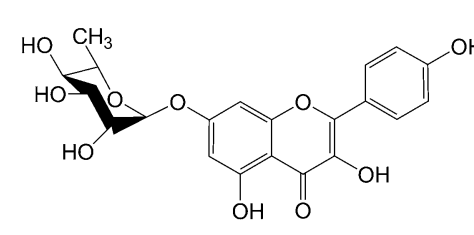

rhamnoisorobin (36)<smiles>COc1cc(O)c2c(=O)c(O)c(-c3ccc(O)c(O)c3)oc2c1</smiles>

rhamnetin (37)<smiles>O=C(/C=C/c1ccc(O)cc1)OC[C@H](O)[C@H](O)[C@H](O)[C@H](O)Oc1c(-c2ccc(O)cc2)oc2cc(O)cc(O)c2c1=O</smiles>

tiliroside (38)

Fig. 3 Chemical structures of flavonols

phospholipids can induce structural changes in the properties of the membrane (e.g., thickness and fluctuations) and indirectly modulate the distribution/function of membrane proteins, as well as influence pharmacological properties of flavonoids themselves (Arora et al. 2000). However, the mechanism responsible for the flavonoid-membrane interaction has not yet been fully understood and the 
Fig. 4 Chemical structures of flavanols (catechins)

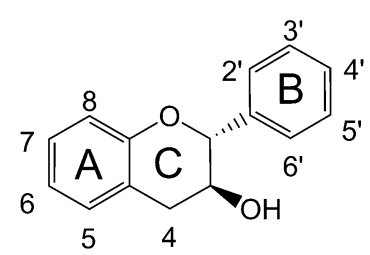

flavanol (catechin) subclass backbone<smiles>Oc1cc(O)c2c(c1)O[C@H](c1ccc(O)c(O)c1)[C@H](O)C2</smiles>

epicatechin (EC) (39)<smiles>O=C(O[C@H]1Cc2c(O)cc(O)cc2O[C@@H]1c1cc(O)c(O)c(O)c1)c1cc(O)c(O)c(O)c1</smiles>

gallocatechin-3-gallate (GCG) (41)<smiles>CCCCCCCC(=O)O[C@H]1Cc2c(O)cc(O)cc2O[C@H]1c1ccc(O)c(O)c1</smiles>

3-O-octanoyl-epicatechin (43)<smiles>O=C(O[C@H]1Cc2c(O)cc(O)cc2O[C@@H]1c1ccc(O)c(O)c1)c1cc(O)c(O)c(O)c1</smiles>

epicatechin-3-gallate (ECG) (40)<smiles>O=C(O[C@H]1Cc2c(O)cc(O)cc2O[C@@H]1c1cc(O)c(O)c(O)c1)c1cc(O)c(O)c(O)c1</smiles>

epigallocatechin-3-gallate (EGCG) (42)<smiles>Oc1ccc(C2Oc3cc(O)cc(O)c3CC2O)cc1</smiles>

5,7,4'-trihydroxyflavanol (44) literature so far remains controversial (Sanver et al. 2016).

Catechins (Fig. 4) are often linked to the antimicrobial effects and related to the interactions with the cell membrane. Contrasting to the protective effects of flavonoids on membranes, catechins were shown to rupture the bacterial membrane by binding to the lipid bilayer and by inactivating or inhibiting the synthesis of intracellular and extracellular enzymes (Reygaert 2014). Moreover, recent studies employing cell models have highlighted the pro-oxidative activity of several polyphenols already known as antioxidants, 


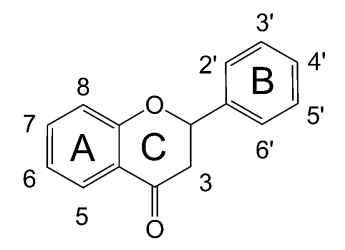

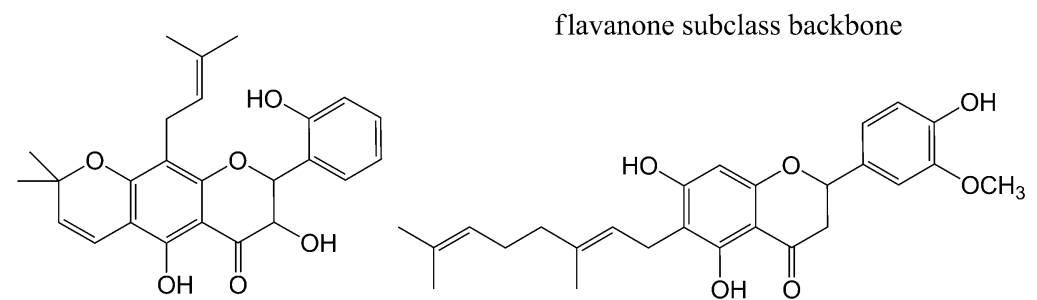

2-hydroxylupinifolinol (45)<smiles>CC(C)=CCC/C(C)=C/Cc1c(O)cc2c(c1O)C(=O)CC(c1ccc(O)c(O)c1)O2</smiles>

diplacone (48)<smiles>O=C1CC(c2ccc(O)cc2)Oc2cc(O)cc(O)c21</smiles>

naringenin (51)
3'-O-methyldiplacol (46)<smiles>O=C1CC(c2ccc(O)c(O)c2)Oc2cc(O)cc(O)c21</smiles>

eriodictyol (49)<smiles>CC(C)=CCc1c(O)c(CC=C(C)C)c2c(c1O)C(=O)CC(c1ccc(O)c(O)c1)O2</smiles>

6,8-diprenyleriodictyol (47)<smiles>COc1ccc(C2CC(=O)c3c(O)cc(O)cc3O2)cc1O</smiles>

hesperetin (50)<smiles>COc1cc(O)c2c(c1)OC(c1ccccc1)CC2=O</smiles>

pinostrobin (53)<smiles>C=CC(C/C=C\C)Cc1c(O)cc(O)c2c1OC(c1ccc(O)cc1O)CC2=O</smiles>

Fig. 5 Chemical structures of flavanones

namely epicatechin (EC, compound 39), epigallocatechin gallate (EGCG, compound 42) and a flavonol quercetin (32) (Bouayed and Bohn 2010). Fathima and Rao (2016) reported that the mode of action of killing bacteria by catechins was found to be an oxidative burst by the generation of reactive oxygen species (ROS) that cause alteration in the membrane permeability and membrane damage. It should be noted however, that oxidative bursts occur only at high EGCG concentrations. Liposome studies also showed 


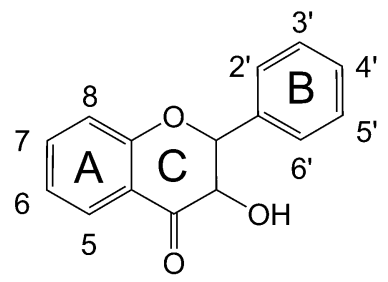

flavanonol subclass backbone<smiles>O=C1c2c(O)cc(O)cc2OC(c2ccc(O)cc2)C1O</smiles>

dihydrokaempferol (57)<smiles>COc1cc(C2Oc3cc(C4Oc5cc(O)cc(O)c5C(=O)C4O)ccc3OC2CO)ccc1O</smiles>

silibinin (58)<smiles>COc1cc(C2Oc3cc(C4Oc5cc(O)cc(O)c5C(=O)C4O)ccc3OC2CO)ccc1O</smiles>

silymarin (59)<smiles>O=C1c2c(O)cc(O)cc2OC(c2ccc(O)c(O)c2)C1O</smiles>

taxifolin (60)

Fig. 6 Chemical structures of flavanonols

membrane disruption by this compound (Sirk et al. 2009). Interestingly, liposomes containing high amounts of negatively charged lipids, were less susceptible to catechin damage, just as catechins have less effect on Gram-negative bacteria due to negatively charged LPS of the outer bacterial membrane (Ikigai et al. 1993). It correlates well with studies reporting lower antibacterial activities of catechins against Gram-negative bacteria versus Gram-positive bacteria (Cushnie et al. 2008). Cushnie et al. (2008) reported that membrane disruption by catechins causes potassium leakage in methicillin-resistant Staphylococcus aureus (MRSA) strain, which is the first indication of a membrane damage in microorganisms (Lambert and Hammond 1973). They have also noticed that more lipophilic, acylated to 3-O-octanoyl-epicatechin (43) yields better results in antibacterial studies, than unmodified epicatechin (39). The increased activities are the result of enhanced membrane affinity of their long acyl chains (Matsumoto et al. 2012).

Other flavonoids are also often reported to possess membrane-disrupting activities. Sato et al. (1997) reported that 2,4,6'-trihydroxy-3'-methylchalcone (62) leads Streptococcus mutans to leak intracellular substances such as protein and ions. Mirzoeva et al. (1997) noticed that quercetin (32) from propolis causes a decrease of proton-motive force in S. aureus and suggested that increased membrane permeability contributes to the synergistic activity of propolis with antibiotics, such as tetracycline and ampicillin (Stepanovic et al. 2003). Furthermore, Ollila et al. (2002) showed that flavones acacetin (9) and apigenin (10), as well as flavonols morin (26) and rhamnetin (37), caused destabilization of the membrane structure by disordering and disorientation of the membrane lipids 


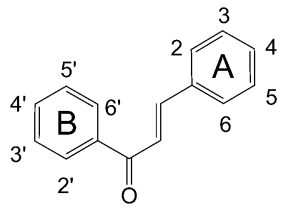

chalcone subclass backbone

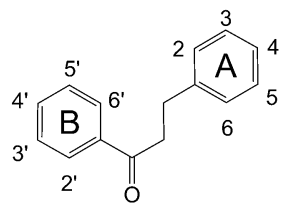

dihydrochalcone subclass backbone<smiles>O=C(/C=C/c1ccc(O)cc1)c1ccc(O)cc1O</smiles><smiles>Cc1ccc(O)c(C(=O)/C=C/c2ccc(O)cc2O)c1</smiles><smiles>C=C(C)C(O)Cc1cc(C(=O)/C=C/c2ccc(O)c(CC=C(C)C)c2)c(O)cc1O</smiles><smiles>O=C(/C=C/c1ccc(O)c(O)c1)c1ccc(O)cc1O</smiles>

4,2',4'-trihydroxychalcone (61) 2,4,6'-trihydroxy-3'-methylchalcone (62) bartericin A (63)

butein (64)<smiles>O=C(/C=C/c1ccc(O)cc1O)c1ccccc1O</smiles><smiles>CC(C)=CCc1c(O)ccc(C(=O)/C=C/c2ccc(O)cc2)c1O</smiles>

isoliquiritigenin (65) isobavachalcone (66)<smiles>COc1cc(O)c(C=CC(=O)c2ccc(O)cc2)cc1O</smiles>

licochalcone A (69)<smiles>COc1c(/C=C/C(=O)c2ccc(O)cc2)ccc(O)c1O</smiles>

licochalcone B (70)

Fig. 7 Chemical structures of chalcones. It should be noted that positions of substituents in semi-systematic names may differ compared to original reports due to variations in numeration of the positions of the rings in chalcone structures. We adjusted the

and induced leakage from the vesicle. Tsuchiya and Iinuma (2000) reported that flavanones naringenin (51) and sophoraflavanone G (56) have antibacterial activity against MRSA. They have also noticed that the antibacterial effect of these flavonoids is caused by reducing the fluidity in hydrophilic and hydrophobic regions of the both inner and outer cellular membrane. Sanver et al. (2016) showed that flavonols quercetin (32), rutin (quercetin-3-O-rhamnoglucoside, compound 35) and tiliroside (38) decreased the bilayer thickness, furthermore rutin disrupted the lipid monolayer structure. Synthetic lipophilic 3-arylideneflavanones (substituted with various phenolic compound<smiles>COc1cc(O)c(C(=O)C2C(CC=C(C)C)C(C)=CCC2c2ccccc2)c(O)c1</smiles>

panduratin A (67)<smiles>O=C(CCc1ccc(O)cc1)c1c(O)cc(O)cc1O</smiles>

phloretin (68)<smiles>COc1c(/C=C/C(=O)c2ccc(O)cc2)ccc(O)c1CC=C(C)C</smiles>

licochalcone $\mathrm{C}$ (71)<smiles>COc1c(/C=C/C(=O)c2ccc(O)c(CC=C(C)C)c2)ccc(O)c1O</smiles>

licochalcone D (72)

nomenclature of chalcones in this paper, according to the most common numeration approach (Boumendjel 2003). The chemical structures are consistent with the original reports

at the C-3 position of C Ring) were found to be highly active against $S$. aureus, Staphylococcus epidermidis, and Enterococcus faecalis due to flavonoid-initiated bacterial cell aggregation that influences the integrity of membranes and causes biofilm disturbance (Budzynska et al. 2011).

Concluding, differences in the number and distribution of hydroxyl groups, the polymerization degree, as well as the presence of a methoxy groups in the $\mathrm{C}$ ring, can influence the type of interactions that occur between different flavonoids and lipid bilayers (Oteiza et al. 2005). Moreover, flavonoids lacking hydroxyl groups on their B Rings are more active against 

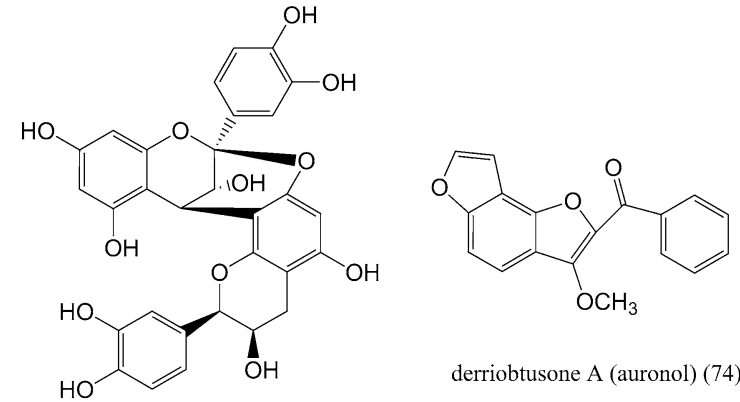

derriobtusone A (auronol) (74)

A-type proanthocyanidin (monomer) (73)

Fig. 8 Chemical structures of other flavonoids mentioned in this paper

microbial membranes than those with the $-\mathrm{OH}$ groups (Chabot et al. 1992). This is due to negative correlation between the relative hydrophobicity of flavonoids and the number of hydroxyl group present. Furthermore, other authors suggest that lipophilic flavonoids which are highly hydroxylated can be more disruptive for membrane structure (Matijašević et al. 2016; Mishra et al. 2009; Sato et al. 1996). It is worth noting that bacterial membrane damage by catechins and other flavonoids may also result in an inability of the bacteria to secrete toxins (Lee et al. 2011; Shah et al. 2008).

\section{Biofilm formation}

Bacterial biofilm-based infections constitute a significant amount of all microbial and chronic infections in animals and humans, as well as in food spoilage (Abdullahi et al. 2016; Jamal et al. 2018). One of the crucial features of bacteria growing as biofilms is that they become from 10 to 1000 times more resistant to antimicrobial agents when compared to their planktonic cells (Kon and Rai 2016). The current medicinal approaches to eradicate biofilm bacteria using systemic antibiotic treatments are very limited. However, antibiofilm phytochemical compounds were shown to influence the bacterial biofilm establishment and growth as well as the related bacterial adhesion, motility, and quorum sensing (QS). Furthermore, these compounds are believed to have a lower probability of bacterial resistance occurrence (Borges et al. 2013).

Although the initiation of biofilm formation has been thought to be due to random attachment of single cells to a surface, which is followed by cells dividing and developing into mature, three-dimensional biofilms (Costerton et al. 1995). However, Kragh et al. (2016) have showed that multi cellular bacteria composites perform better than single cells during the biofilm development. Interestingly, there are reports of flavonoids supporting bacterial aggregation. Stapleton et al. (2004) observed pseudo multicellular aggregates of $S$. aureus after incubation with EGCG (42) and 3-O-octanoyl-epicatechin (43). Flavonols have also been reported to cause aggregations of bacterial cells, particularly galangin (25) (Cushnie et al. 2007). It should be noted however, that growth of the bacteria was inhibited after aggregation. Presumably, flavonoids cause bacterial aggregation by their partial lysis, which leads to membrane fusion, and consequently reduces the active nutrient uptake via a smaller membrane area, thus it cannot be stated that flavonoids support biofilm formation. On the contrary, multiple research teams reported that flavonoids in fact inhibit biofilms. For example, Awolola et al. (2014) showed a significant antibiofilm activity of isovitexin (apigenin-6-C-glycoside 14), EC (39) and 5,7,4'-trihydroxyflavanol (44) against $S$. aureus ATCC 29213. Similarly, El-Adawi (2012) observed a 55-66\% decrease in $S$. mutans biofilm formation upon exposure to $2-15 \%$ EC. However, Nyila et al. (2012) observed that EC from Acacia karroo did not reduce Listeria monocytogenes biofilms.

Quorum sensing, in particular, autoinducer-2-mediated cell-cell signaling, was proposed as a significant regulatory factor for the biofilm production in Escherichia coli, Vibrio spp., and Salmonella typhimurium (Vikram et al. 2010). Interestingly, citrus flavonoids, such as apigenin (10), kaempferol (28), quercetin (32) and naringenin (51) are effective antagonists of cell-cell signaling (Vikram et al. 2010). Furthermore, quercetin (assigned with antileishmanial and antibacterial activities (Gatto et al. 2002; Prasad et al. 2014)) was shown to inhibit enteroaggregative E. coli EAEC 042 biofilm (Barboza et al. 2016). Quercetin inhibited alginate production in a concentration-dependent manner, resulting in the declination in the adherence during biofilm formation. Moreover, this flavonoid inhibited $\mathrm{N}$-acyl homoserine lactones (AHL)-mediated QS. Most notably, quercetin upregulates the expression of several iron siderophore proteins limiting the amount of $\mathrm{Fe}^{3+}$ that is required for the biofilm formation of Pseudomonas aeruginosa 
(Ouyang et al. 2016; Symeonidis and Marangos 2012). Kaempferol (28), epicatechin gallate (ECG, compound 40) and EGCG (42) were reported to mediate the displacement of AHL molecules from LuxR-type transcriptional activator protein (Roy et al. 2017), while chrysin (12), phloretin (68) and naringenin (51) inhibited QS synthase/receptor pairs, LasI/R, and RhlI/R (Paczkowski et al. 2017). Cranberry A-type proanthocyanidins (Fig. 8) are also found to be antiadhesion agents against the Gram-negative bacterium P. aeruginosa (Ulrey et al. 2014). Ulrey et al. (2014) suggested that the mechanism of A-type proanthocyanidins against the biofilm formation results from their chelating properties.

Hydrophilic flavonoids can interact at the membrane surface and provide protective actions against different deleterious agents and biofilm formation (Oteiza et al. 2005). However, Lee et al. (2011) showed that biofilm reduction by flavonoids does not result from their antioxidant properties alone. They demonstrated that flavones, such as 6-aminoflavone (1), 6-hydroxyflavone (2), apigenin, chrysin (12), as well as isoflavones daidzein (21) and genistein (22), and a dihydrochalcone phloretin (68) had inhibitory effects on E. coli O157:H7 biofilm formation, although antioxidant compounds (vitamin $\mathrm{C}$ and vitamin E) did not show such effect. Furthermore, phloretin (a natural, nontoxic apple flavonoid) caused the most significant reduction of enterohemorrhagic E. coli $\mathrm{O} 157: \mathrm{H} 7$ biofilms without affecting the growth of planktonic cells. Similar effect was showed for the auronol called derriobtusone A (74) that inhibited the biofilm formation in E. coli, although the planktonic growth of $E$. coli was only weakly inhibited (Vasconcelos et al. 2014). Notably, phloretin (68) showed a dose-dependent inhibition of biofilm and did not harm commensal E. coli $\mathrm{K}-12$ and nonpathogenic $E$. coli ATCC 4157 biofilm (Lee et al. 2011). This is an important feature of phloretin, since antibiofilm agent should be able to selectively inhibit the pathogenic strains without wiping out the commensal microflora.

Fimbriae, including curli and pili, are important factors for the biofilm formation (Rendón et al. 2007). Phloretin (68) reduced fimbriae formation in E. coli O157:H7, due to repression of the expression of the curli genes ( $\operatorname{csg} A$ and $\operatorname{csg} B$ ) (Lee et al. 2011). This study also reported that phloretin repressed the expression of two toxin genes (hemolysin $h l y E$ and
Shiga toxin 2 stx2). However, phloretin was also shown to induce stress resistance genes, such as $\operatorname{marR} A B$ and hcsBA genes (Lee et al. 2011). Thus, phloretin could positively influence the antibiotic resistance as well.

Efflux-pump inhibitors (EPI) are aimed not only to block the efflux pumps, but also the biofilm formation (Sana et al. 2015). Pinostrobin (a dietary flavanone discovered in the wood of pine, Pinus strobus, compound 53) enhanced membrane permeability in both Gram-positive and Gram-negative bacteria ( $E$. faecalis, S. aureus, E. coli and P. aeruginosa), which correlated well with its effect on EPI and antibiofilm formation in Gram-negative bacteria (Christena et al. 2015). Christena et al. (2015) suggested that pinostrobin exerts its antibiofilm effect by the mechanism that is unrelated to its EPI effect and may not involve the repression of curli genes. This is in contrast to the report of pinostrobin EPI effect in S. typhimurium (Baugh et al. 2012). Tea EGCG (42) provides another example of effective antimicrobial agent against both the planktonic and biofilm forms of E. faecalis. Tea EGCG inhibits not only the bacterial growth, but also suppresses the expression of specific genes related to biofilm formation (Lee and Tan 2015). A number of prenylated flavonoids isolated from Epimedium species inhibited Porphyromonas gingivalis biofilm formation, however, the antibiofilm mechanism of those flavonoids remains unknown (Kariu et al. 2016; Olczak et al. 2005).

Inhibition of cell envelope synthesis

Bacterial-type II fatty acid synthase (FAS-II) differs in many ways from the mammalian one (FAS-I), which makes it excellent target for an antimicrobial agent. Multiple inhibitors of the FAS-II components have been reported to date and summarized below. Quercetin (32), apigenin (10), and sakuranetin (54) were shown to inhibit 3-hydroxyacyl-ACP dehydrase from Helicobacter pylori (Zhang et al. 2008b). Extensive research has been made on 3-ketoacylACP synthase from E. faecalis and 11 flavanones with different configurations of hydroxyl groups have been screened (Jeong et al. 2009). The best result was obtained for the use of eriodictyol (49), naringenin (51) and taxifolin (60). Parallel docking studies, conducted by the same team, indicate that hydrogen bonds between flavonoid hydroxyl groups at C-4' and 
C-5' of B ring and enzyme amino acid residues Arg38 and Phe 308 were the key for their antibacterial activity (Figs. 5, 6). Elmasri et al. (2017) reported 5,6,7,4',5'pentahydroxyflavone (3) and 5-hydroxy-4',7dimethoxyflavone (5) to downregulate the malonyl CoA-acyl carrier protein transacylase fabD (MCATs) that regulates bacterial FAS-II. Thus, these two flavones are considered to be the promising drugs for blocking the bacterial growth. Furthermore, EGCG (42) from green tea inhibited specific reductases (FabG, FabI) in the bacterial FAS-II (Zhang and Rock 2004). FabG enzyme (beta-ketoacyl-[acyl carrier protein] reductase) participates in the fatty acid biosynthesis and is the only known isoenzyme to catalyze the reduction of the bacterial membrane $\beta$ keto groups ( $\mathrm{Li}$ et al. 2006). Therefore, this enzyme is an ideal target for the development of new antibiotics. Inactivation of FabG probably occurs as a result of EGCG-induced aggregation of this enzyme. Finally, other enzymes involved in fatty acid biosynthesis, such as 3-ketoacyl-ACP reductase and enoyl-ACP reductase from many bacteria are inhibited by EGCG as well (Li et al. 2006; Zhang et al. 2008a; Zhang and Rock 2004).

Mycobacteria cause some of the most serious diseases, which are notoriously difficult to treat (Chen et al. 2010). The presence of mycolic acids is one of the most distinctive and essential survival features of the mycobacterial cell wall. Those bacteria possess two types of fatty acid synthases, a mammalian-type FAS-I, and a bacterial-type FAS-II, both of which are important for the biosynthesis of mycolic acid. A number of flavonols have been shown to inhibit FAS-I, including: quercetin (32), kaempferol (28), fisetin (24), morin (26) and myricetin (27), as well as flavones baicalein (11) and luteolin (15), and EGCG (42) (Li and Tian 2004). Moreover, some of these flavonoids possessed activity against FAS-II components as well, including enoyl-ACP-reductase, $\beta$-ketoacyl-ACP reductase, and $\beta$-hydroxyacyl-ACP dehydratases (Brown et al. 2007). Furthermore, Brown et al. (2007) reported that chalcones $4,2^{\prime}, 4^{\prime}$-trihydroxychalcone (61), butein (64), isoliquirtigenin (65), and a flavonol fisetin (24) possess inhibitory activity against FAS-II from Mycobacterium bovis BCG.

Peptidoglycan is an essential component of the bacterial cell wall, and the inhibition of its synthesis is a common mechanism of action of conventional antimicrobial drugs and flavonoids. Baicalein (flavone from Scutellaria baicalensis, 11) supported induced by EGCG (42) peptidoglycan damage (Fujita et al. 2005). Flavonols galangin (25), kaempferide (30), and kaempferide-3-O-glucoside (31) showed not only activity against amoxicillin-resistant $E$. coli, but also the ability to reverse the resistance via inhibition of peptidoglycan and ribosome synthesis (Eumkeb et al. 2012). Another study on the mechanism of action of catechins showed that they interfere with the biosynthesis of the bacterial cell wall by binding with the peptidoglycan layer. Cell wall synthesis was also inhibited by a synergistic effect of EGCG (42) and DL-cycloserine (an inhibitor unrelated to penicillinbinding protein) (Zhao et al. 2001). Furthermore, since both EGCG and $\beta$-lactams (benzylpenicillin, oxacillin, methicillin, ampicillin, and cephalexin) directly or indirectly target peptidoglycan (Zhao et al. 2001), EGCG synergizes the activity of $\beta$-lactams. Kinetic studies on D-alanine-D-alanine ligase, responsible for the production of the terminal dipeptide of peptidoglycan precursor UDPMurNAc-pentapeptide, showed that quercetin (32) and apigenin (10) inhibit this enzyme (Wu et al. 2008). These two flavonoids bind to the active center of D-alanine-D-alanine ligase (Singh et al. 2013; Wu et al. 2008). However, quercetin had poorer activity compared to apigenin, which is attributed to its additional -OH groups that enforce its affinity to the enzyme (Figs. 1,3). In the contrast, sakuranetin (54), a flavonoid similar to apigenin (it has 7-methoxy instead of 7-hydroxy group, and no double bond on $\mathrm{C}$ ring, Figs. 1, 5), has no inhibitory effect (Wu et al. 2008). Furthermore, the hydrophilic nature of quercetin limits its penetration into the bacterial cell.

Inhibition of nucleic acid synthesis

Flavonoids have been reported to be significant topoisomerases inhibitors, which contributes to their antimicrobial activity. For example, DNA gyrase is an essential enzyme for the DNA replication and it is exclusive to prokaryotes, which makes it an attractive target for antibacterial drugs (Plaper et al. 2003). Ohemeng et al. (1993) reported the inhibition of DNA gyrase from $E$. coli by quercetin (32), apigenin (10), and 3,6,7,3', $4^{\prime}$-pentahydroxyflavone (4). Moreover, in silico analysis suggested that subunit B of DNA gyrase from Mycobacterium smegmatis and M. tuberculosis can be targeted by quercetin (Suriyanarayanan et al. 
2013). This report was confirmed, by the studies conducted on different gyrase subunits that revealed quercetin binding to the B subunit of gyrase and the corresponding blockage of ATP binding pocket by the formation of hydrogen bonds via 5, 7 and $3^{\prime}-\mathrm{OH}$ groups to the amino acid residues of DNA gyrase (Fig. 3) (Plaper et al. 2003). It is in correlation with the studies that reported the blockage of ATP binding pocket of D-alanine-D-alanine ligase by the same flavonoids (Wu et al. 2008). Moreover, the related flavonoids chrysin (12) and kaempferol (28) greatly inhibited DNA gyrase from E. coli (nobiletin (16), tangeritin (19) and myricetin (27) were less efficient inhibitors) (Wu et al. 2013). Those studies showed that flavonoid hydroxyl groups allow better association with the gyrase compared to methoxy groups, although an extra $5^{\prime}-\mathrm{OH}$ in myricetin greatly decreased its gyrase inhibition properties (Fig. 3) (Wu et al. 2013). The second mechanism of DNA gyrase inhibition was proposed by molecular docking studies (Fang et al. 2016; Plaper et al. 2003), which suggest that flavonoids inhibit the DNA supercoiling by competitively interacting with the ATP binding site of the DNA gyrase B subunit (GyrB). In this mechanism of action, flavonoids binding to DNA stabilizes the DNA-gyrase complex that leads to DNA cleavage induction (Plaper et al. 2003). Moreover, Fang et al. (2016) reported 3-hydroxyl, 5-hydroxyl, 7-hydroxyl, and 4-carbonyl groups to be crucially active substituents of flavonoids by interacting with key residues of GyrB. This result is in accordance with previous studies of Wu et al. (2013). Furthermore, Ulanowska et al. (2006) showed that isoflavone genistein (22) inhibits the growth of Vibrio harveyi (with intermediate effect on Bacillus subtilis and little effect on E. coli) in a dose-response manner. They suggested that the inhibition of growth of the bacteria species results from genistein-mediated stabilization of the topoisomerase II-DNA cleavage complex that leads to the impairment of cell division and/or completion of chromosome replication (Verdrengh et al. 2004).

Helicases are ubiquitous motor proteins that separate and/or rearrange nucleic acid duplexes in reactions fueled by adenosine triphosphate (ATP) hydrolysis (Shadrick et al. 2013). Similarly to topoisomerases and gyrases, their function is essential for DNA replication. Recent studies suggested these proteins as molecular targets of flavonoids. Flavones and flavonols, the groups of pharmacophores with nucleic acid binding capacity, have been screened as helicase inhibitors. A flavone luteolin (15) and its structurally related flavonols, such as morin (26) myricetin (27), were shown to inhibit the replicative helicases like DnaB and RecBCD helicase/nuclease of E. coli (Xu et al. 2001). Moreover, myricetin inhibited Gram-negative bacterial growth and was proposed to be a potent inhibitor of numerous DNA and RNA polymerases, as well as viral reverse transcriptases (along with baicalein (11)) (Ono et al. 1990) and telomerases (Griep et al. 2007).

Dihydrofolate reductase (DHFR) is a common target of many drugs, including antimicrobial agents. The DHFR is an important enzyme of the folic acid synthesis pathway, which provides precursor of pyrimidines and purines (Bhosle and Chandra 2016). EGCG (42) was reported to inhibit DHFRs from Streptomonas maltophilia, Mycobacterium tuberculosis, and E. coli (Navarro-Martinez et al. 2005; Raju et al. 2015; Spina et al. 2008). Furthermore, EGCG had synergistic effects with other inhibitors of folic acid pathway, such as sulfamethoxazole and ethambutol (Navarro-Martinez et al. 2005; Raju et al. 2015).

Flavonoid DNA intercalation, that inhibits bacterial nucleic acid synthesis, was also proposed as a mechanism underlying their antimicrobial properties. Mori et al. (1987) noticed that the incubation with EGCG (42), myricetin (27), and robinetin (17) resulted in reduced DNA, RNA, and protein synthesis by Proteus vulgaris and $S$. aureus. They proposed that this process resulted from the intercalation of flavonoids with nucleic acids, mediated by flavonoid-free hydroxyl group at C-3 of A ring and $3^{\prime}, 4^{\prime}, 5^{\prime}$ trihydroxyl motif at $\mathrm{B}$ ring (Figs. 1, 3, 4). However, DHFR inhibition could explain the reduction of DNA and RNA synthesis by EGCG, as well. Furthermore, myricetin and robinetin, which share similar structure, also seem to be the possible DHFR inhibitors. These observations raise the question, "whether those compounds only reduce nucleic acid synthesis via DNA intercalation/DHFR inhibition or they have got multiple target sites?" Giving the low specificity of EGCG, lowered DNA and RNA synthesis could result from multiple enzyme inhibitions and proton-motive force (PMF) disruption. Numerous studies reported on flavonoid-mediated topoisomerase inhibition and DNA intercalation in human cancer cells (reviewed by Russo et al. (2012)), suggesting the universal mechanisms of their action. 
Inhibition of electron transport chain and ATP synthesis

The membrane potential, being the essential main energy source for almost all chemical processes in living systems, is the most important factor for the survival and growth of bacterial cells. Notably, the treatment of $S$. aureus with isobavachalcone (66) and 6-prenylapigenin (7) from Dorstenia species resulted in bacterial membrane depolarization (Dzoyem et al. 2013). Furthermore, Haraguchi et al. (1998) reported that licochalcones from Glycyrrhiza inflata inhibited oxygen consumption in Micrococcus luteus cells, and the site of inhibition was thought to be between CoQ and cytochrome $\mathrm{c}$ in the bacterial electron transport chain. Although licochalcones A, B, C, and D (compounds 69-72) caused inhibition of NADHcytochrome $\mathrm{c}$ reductase activity in the membrane fraction, while cytochrome c oxidase was not inhibited. However, only licochalcones A and C manifested antibacterial activities against Gram-positive bacteria and it was attributed to the presence of lipophilic prenyl moiety on the $\mathrm{D}$ ring of licochalcones $\mathrm{A}$ and $\mathrm{C}$ (Fig. 7), which facilitates their infiltration into the bacterial cell (Haraguchi et al. 1998).

Recently, it has been reported that flavonoids can inhibit $\mathrm{F}_{1} \mathrm{~F}_{\mathrm{O}}$ ATPase of $E$. coli (Chinnam et al. 2010). ATP synthase is a highly conserved enzyme with two sectors, $\mathrm{F}_{1}$ and $\mathrm{F}_{\mathrm{O}}$. In E. coli, $\mathrm{F}_{1}$ is composed of $\alpha 3 \beta 3 \gamma \delta \varepsilon a b 2 c 10$, while $F_{O}$ consists of ab2c10. ATP hydrolysis and synthesis occur on three catalytic sites in the $\mathrm{F}_{1}$ sector, whereas proton movement occurs through the membrane-embedded $\mathrm{F}_{\mathrm{O}}$ (Senior et al. 2002). A wide range of polyphenols has been shown to bind at the distinct polyphenol binding site and inhibit the ATP synthase. The polyphenol binding pocket lies at the interface of $\alpha, \beta$, and $\gamma$-subunits of $F_{1}$ sector. Therefore, the proposed mode of flavonoid inhibitory action was the binding at the polyphenol binding pocket of ATP synthase and the blockage of clockwise or anticlockwise rotation of the $\gamma$-subunit (Gledhill et al. 2007). Furthermore, the polyphenol binding pocket residues are highly conserved among different species including human, bovine, rat, and E. coli (Walker et al. 2000) Thus, there is great chance that other microorganisms may be susceptible to this type of inhibition (Chinnam et al. 2010). The most effective inhibitors of E. coli $\mathrm{F}_{1} \mathrm{~F}_{\mathrm{O}}$ ATPase include baicalein (11), morin (26), EC (39), as well as flavanonols silibinin (58) and silymarin (59) (Chinnam et al. 2010). Furthermore, quercetin (32), quercetin-3-glucoside (isoquercetin, 33) and quercetin-3-O-rhamnoside (quercitrin, 34) are known to prevent the ATP hydrolysis, although not the ATP synthesis (Chinnam et al. 2010). EGCG (42) inhibited the acidogenic and aciduric properties of $S$. mutans, probably by the inhibition of the enzymatic activity of $\mathrm{F}_{1} \mathrm{~F}_{\mathrm{O}}$ ATPase (Xu et al. 2011, 2012). Ulrey et al. (2014) demonstrated that the treatment of $P$. aeruginosa with A-type proanthocyanidins (isolated from Cranberries, monomer shown on Fig. 8-compound 73) downregulated the proteins involved in ATP synthesis: a cytochrome c (NP_251172), hypothetical protein (NP_251171); as well as protein subunits of acetyl-CoA carboxylase (NP_254123), fumarase (NP_253023), and aconitate hydratase (NP_249485).

A decline in the overall bacterial metabolism can lead to the indirect arrest of the biofilm formation, as well. Notably, the 4',5',5-trihydroxy-6,7-dimethoxyflavone (8) (from Teucrium polium) was reported to affect the F-type ATP synthase (atpD) and thus reduce the ATP availability in S. aureus (Elmasri et al. 2017).

Antibacterial action of flavonoid-metal complexes

Havsteen (2002), in his voluminous paper on flavonoid properties, tried to explain the antibacterial activities of flavonoids. Since many studies showed the ability of flavonoids to chelate transition metal ions (Karlíčková et al. 2015; Li et al. 2015; Riha et al. 2014; Samsonowicz et al. 2017), he pointed out that many flavonoids could cause the inhibition of bacterial metal enzymes. This mechanism of action is common for many other antibacterial substances, including lactoferrin from human milk.

Flavonoid chelation sites include two proximal hydroxyl groups (o-dihydroxyl group in ring B or ring $\mathrm{A})$, the 3-hydroxy-4-keto group of the $\mathrm{C}$ ring or via the 5-hydroxy-4-keto position of the $\mathrm{A}$ and $\mathrm{C}$ rings. Although the antibacterial activity of complexes depends strongly on the metal ion, the preferred metal binding site depends on the flavonoid, and on the $\mathrm{pH}$ value (Kasprzak et al. 2015). Literature data suggested that the flavonoids predominantly form complexes with a metal in 1:2 ratio and that their binding efficiency is also associated with the transition state of metal ions (e.g., $\mathrm{Fe}^{2+}>\mathrm{Fe}^{3+}$ ) (Ren et al. 2008). One of the well-known flavonoid-metal complexes are the 
quercetin (32) complexes. Bravo and Anacona (2001) demonstrated that $\mathrm{Mn}^{2+}, \mathrm{Hg}^{2+}, \mathrm{Co}^{2+}$, and $\mathrm{Cd}^{2+}$ complexes of quercetin show bactericidal effect against $S$. aureus, Bacillus cereus, P. aeruginosa, E. coli, and Klebsiella pneumoniae. Comparatively, quercetin alone at the same concentration had no activity. Similar reports are available for morin (26, $\mathrm{Mg}^{2+}$ and $\mathrm{Ca}^{2+}$ complexes) against Micrococcus flavus and S. aureus (Panhwar and Memon 2011) and 4',7-dimethylapigenin $\left(6, \mathrm{Cu}^{2+}, \mathrm{Ni}^{2+}, \mathrm{Co}^{2+}\right.$, $\mathrm{Zn}^{2+}, \mathrm{Fe}^{3+}, \mathrm{Cr}^{3+}, \mathrm{Cd}^{2+}$, and $\mathrm{Mn}^{2+}$ ) against E. coli, S. aureus, and P. vulgaris (Wang et al. 1992). Despite these studies, the antibacterial mechanism of flavonoid-metal complexes have not been conclusively established yet. For example, the $\mathrm{La}^{3+}$ and $\mathrm{Gd}^{3+}$ (their metal-ligand ratio was $6: 3$, and $8: 3$, respectively) complexes of morin (26) had lesser antibacterial activity, when compared to their parent flavonoids (Kopacz et al. 2005). Complexation with metal ions causes changes in the flavonoid structure, in their affinities to various intracellular targets, as well as in their antioxidant and prooxidant properties. Hence, the different antibacterial activities of the flavonoid-metal ion complexes result from their interaction with different targets than their parent flavonoids. By all means, an antimicrobial resistance to metals (reviewed by Hobman and Crossman (2015)) cannot be excluded.

\section{Inhibition of bacterial toxins}

Important virulence factors, such as bacterial hyaluronidases (produced by both Gram-positive and Gramnegative bacteria), directly interact with host tissues or mask the bacterial surface from host's defense mechanisms. In the bacterial pathogenesis, hyaluronidasemediated degradation of hyaluronan increases the permeability of connective tissues and decreases the viscosity of body fluids (Girish and Kemparaju 2007). Notably, flavonols, such as myricetin (27) and quercetin (32) have been identified as hyaluronic acid lyase (Hyal B) inhibitors in Streptococcus agalactiae. The inhibitory effect of the flavonoids increased with the number of hydroxyl groups present in the flavonoid structure (Hertel et al. 2006). However, hyaluronate lyases from Streptomyces hyalurolyticus (Hyal S), and Streptococcus equisimilis (Hyal C) were only inhibited slightly (Hertel et al. 2006).
Flavonoids, especially catechins and proanthocyanidins (due to antioxidant properties), were proposed to neutralize bacterial toxic factors originating from Vibrio cholerae, S. aureus, Vibrio vulnificus, Bacillus anthracis, and Clostridium botulinum (Ahmed et al. 2016; Choi et al. 2007; Delehanty et al. 2007). Similarly, genistein (22) inhibited the exotoxin from $S$. aureus, while kaempferol (28), kaempferol-3-O-rutinoside (29), and quercetin glycoside inhibited the neurotoxin from $C$. botulinum (Sawamura et al. 2002). The $\alpha$-hemolysin (Hla), a member of bacterial pore-forming $\beta$-barrel toxins, is one of the most important virulence factors produced by $S$. aureus. Soromou et al. (2013) reported that pinocembrin (52), a honey flavanone, reduced $S$. aureus $\alpha$-hemolysin production in a concentrationdependent manner (pinocembrin reduces the transcription level of $\mathrm{Hla}$ and $\delta$-haemolysin genes). Pinocembrin have also been studied to evaluate its mechanism of actions on the bacterial membranes of Neisseria gonorrhoeae. Although the pinocembrininduced cell lysis has been observed in the study, mechanisms of actions of this compound have not been fully elucidated (Rasul et al. 2013; Ruddock et al. 2011). Sugita-Konishi et al. (1999) reported that EGCG (42) and gallocatechin gallate (GCG, 41) suppressed the release of verotoxin from enterohemorrhagic E. coli cells and concluded that green tea catechins can be used to prevent the food poisoning caused by E. coli.

In conclusion, flavonoids manifest many interesting mechanisms of antibacterial action (Fig. 9). There are however, antibacterial flavonoids with little known mechanism, as well as the ones with multiple cellular targets. Further investigation of action mechanisms and structure-activity relationship could help us not only to reveal novel antimicrobials, but also to find the most target-specific ones, which in case of possible therapeutic application of flavonoids, remains critical.

\section{Flavonoids as antimicrobial potentiators}

Mechanism of resistance to antibacterial agents

Pathogenic bacteria may gain the resistance to antibiotic drugs through different mechanisms, such as prevention of interaction of the drug with the target, efflux of the antibiotic from the cell, and direct 


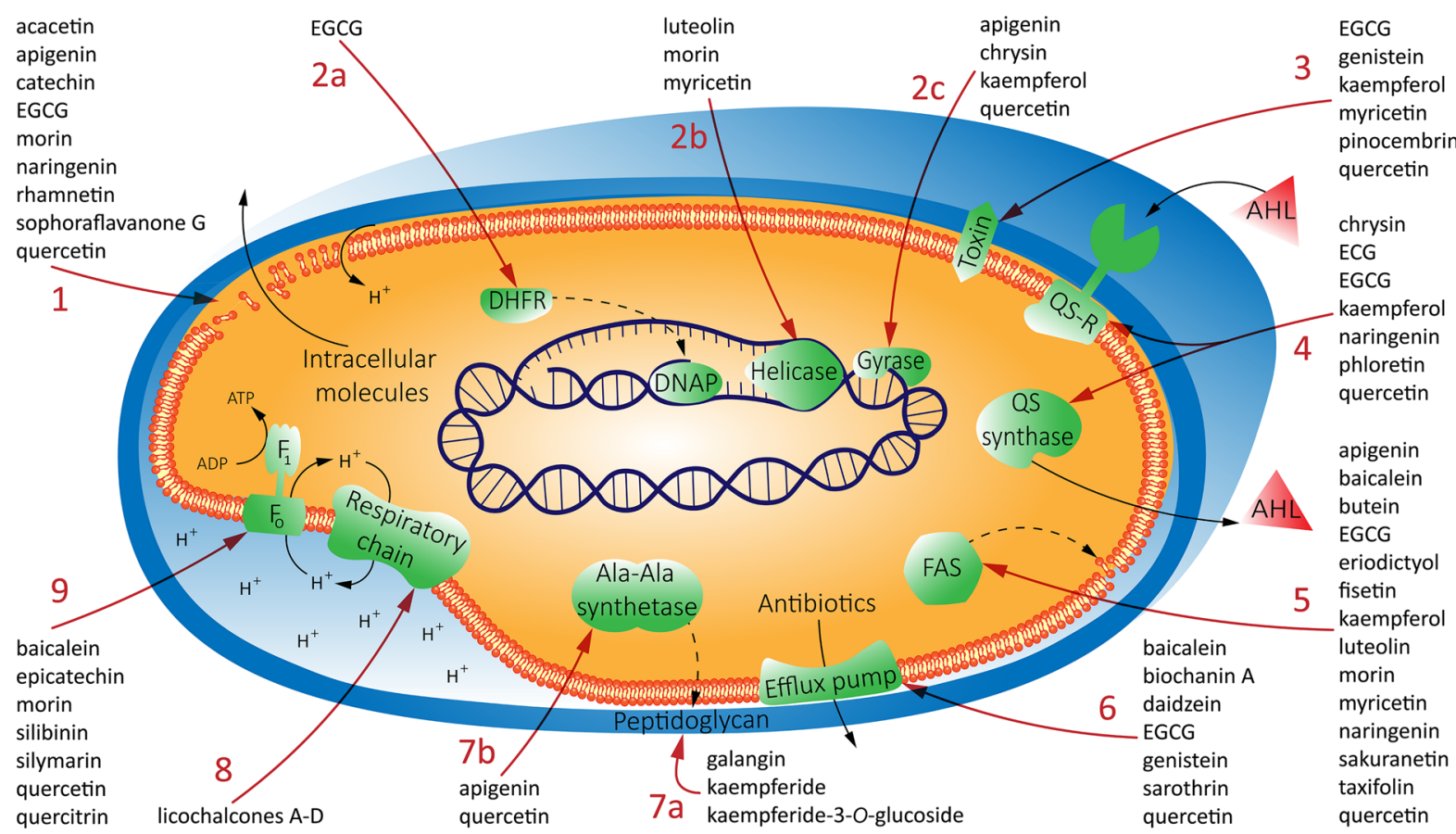

Fig. 9 Diagrammatic representation of action mechanism of flavonoids. Flavonoids can kill or inhibit bacterial cells in variety of ways, such as causing membrane disruption (1) and inhibition of nucleic acid synthesis ( $2 \mathrm{a}$-inhibition of dihydrofolate reductase (DHFR), $2 \mathrm{~b}$ - helicase inhibition, 2c-gyrase/topoisomerase inhibition), as well as inhibit bacterial virulence, e.g. toxins (3) and quorum sensing, which impairs their ability to form biofilms (4). Antimicrobial action can be also executed through inhibition of cell envelope synthesis,

destruction or modification of the drug compound (Fig. 10). Moreover, bacteria can share the resistance genes, for example, the gene of $\beta$-lactamase, an enzyme hydrolyzing the amide bond in the $\beta$-lactam ring through transformation (incorporation of naked DNA), transduction (phage-mediated), and conjugation (Fig. 10). Gram-negative bacteria prefer $\beta$-lactam ring hydrolysis, whereas resistance to in Gram-positive bacteria is mostly achieved by modifications of the target site of antibiotics (Bush 2013; Bush and Fisher 2011).

Another bacterial strategy to cope with the presence of antibiotics is to produce enzymes that inactivate the drug by adding specific chemical moieties to this compound. In the case of Gram-negative bacteria, the aminoglycoside group of antibiotics becomes ineffective due to the phosphorylation, adenylation, or acetylation of the antibiotic molecule (Munita and which involves inhibition fatty acid synthase (FAS-5) and peptidoglycan synthesis ( $7 \mathrm{a}$-inhibition of Ala-Ala dipeptide synthesis, 7b-inhibition of peptidoglycan cross-linking). Flavonoids can inhibit efflux pumps as well, which can lead to reversing antimicrobial resistance (6). Moreover inhibition of NADH-cytochrome c reductase activity in the bacterial respiratory chain (8) and inhibition of ATP synthase (9) were also reported

Arias 2016). The aminoglycoside-modifying enzymes (AMEs) that covalently modify the hydroxyl or amino groups of the aminoglycoside molecule become the predominant mechanism of aminoglycoside resistance worldwide (Ramirez and Tolmasky 2010). Furthermore, the chloramphenicol acetyltransferases chemically inactivate chloramphenicol in both Grampositive and Gram-negative bacteria (Schwarz et al. 2004).

Bacteria have also developed mechanisms that decrease the antibiotic uptake by preventing the antibiotic from reaching its intracellular or periplasmic target. Hydrophilic molecules such as $\beta$-lactam antibiotics, tetracyclines, and some fluoroquinolones are translocated through the membrane by water-filled diffusion channels known as porins (i.e., $\mathrm{OmpF}$, OmpC, and PhoE) (Pages et al. 2008). Bacteria decrease porin-mediated antibiotic uptake by either a 


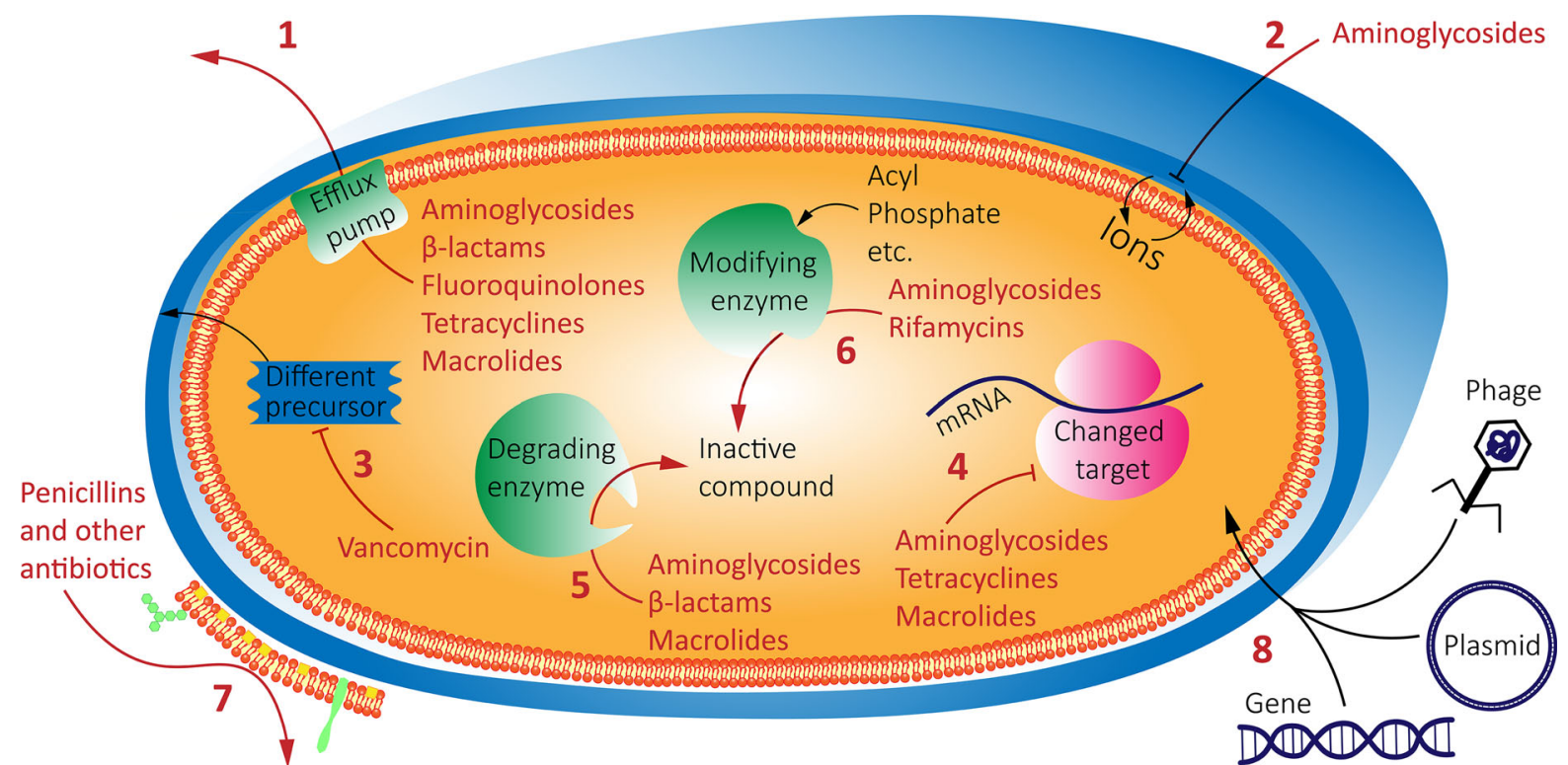

Fig. 10 Diagrammatic representation of mechanisms of antibiotic resistance. Antibiotic resistance can be executed in many different ways, such as efflux of the antibiotics from the bacterial cell (1); changing membrane potential, which prevents antibiotic molecules from entering (2); bypassing target site of the antibiotic through incorporation of changed precursor (3) or changing target site by methylation of RNA, mutations, etc. (4). Antibiotic action can also be abolished through degradation (5)

shift in the type of porins expressed (DomenechSanchez et al. 2003), or by changing the level of porin expression, as well as by impairing the function of these channels (Fernández and Hancock 2012). Moreover, the described changes in the membrane permeability are often accompanied by an increased expression of efflux pumps, in both Gram-negative and Gram-positive bacteria. The efflux pumps may be substrate-specific (tetracycline or macrolides, such as erythromycin in pneumococci) or have broad substrate specificity, which is common for multidrug resistance bacteria (MDR) (Poole 2005). There are six major families of efflux pumps: the ATP-binding cassette (ABC) superfamily (Lubelski et al. 2007), the major facilitator superfamily (MFS) (Pao et al. 1998), the multidrug and toxic compound extrusion (MATE) (Lu 2016), the small multidrug resistance (SMR) family (Bay et al. 2008) (a member of the much larger drug/ metabolite transporter family (DMT) (Piddock 2006)), the resistance nodulation division (RND) superfamily (Nikaido and Takatsuka 2009), and newly discovered proteobacterial antimicrobial compound efflux pump and chemical modification of antibiotic molecules (6). Moreover, Gram-negative bacteria are resistant to penicillin and other hydrophilic antibiotics due to the low permeability of their outer membrane, as well as low expression of porins (7). Furthermore, bacteria can gain and exchange the resistance genes through transduction (phage-mediated), conjugation (acquiring plasmid DNA) and transformation (incorporation of naked DNA) (8)

(PACE) (Hassan et al. 2013). These families differ in terms of structural conformation, a range of substrates, energy sources, and in the types of bacterial organisms in which they are distributed (Soto 2013).

The last common mechanism of antibiotic resistance is interfering with an antibiotic target site either by preventing the antibiotic to reach its binding site (target protection) or by target site modification that decreases an antibiotic binding affinity. Examples of drugs affected by this mechanisms include tetracycline $[\mathrm{Tet}(\mathrm{M})$ and $\mathrm{Tet}(\mathrm{O})]$, fluoroquinolones (Qnr), and fusidic acid (FusB and FusC) resistance (Munita and Arias 2016). Tet(O) and Tet(M) proteins interact with the ribosome and dislodge the tetracycline from its binding site in a GTP-dependent manner, restoring the protein synthesis (Donhofer et al. 2012; Li et al. 2013). The quinolone resistance protein Qnr belongs to the pentapeptide repeat protein family and it acts as a DNA homologue competing for the DNA binding site of the DNA gyrase and topoisomerase IV. The reduction in the DNA gyrase-DNA interaction prevents the quinolone molecule from forming the lethal 
DNA-quinolone complex (Aldred et al. 2014). The antibiotic target site changes may also result from point mutations in the genes encoding these targets, enzymatic alterations of the binding sites by methylation, or by "replacement or bypass of the target site". Classical examples of mutational resistance include development of rifampin (RIF) resistance (Campbell et al. 2001) and the resistance to oxazolidinones (linezolid and tedizolid) (Chen et al. 2013). The resistance to erythromycin is achieved through the enzymatic modification of its target site by the ribosome methylation, which is being catalyzed by ribosomal methylases (encoded by the Erm genes) (Leclercq and Courvalin 2002). The "replacement or bypass of the target site" strategy is used by the bacteria that are resistant to vancomycin. This antibiotic kills bacteria by preventing their cell wall synthesis by binding to nascent peptidoglycan precursors (D-Ala-D-Ala) and forming a cap that results in the loss of cross-linking in the polypeptide chain (Gardete and Tomasz 2014). The vancomycin-resistant bacteria produce a different variant of the peptidoglycan precursors (D-alanyl-D-serine or D-alanyl-D-lactate) or completely destroy the "normal" D-Ala-D-Ala ending precursors (Hiramatsu 2001; McGuinness et al. 2017).

Occasionally the resistance to antimicrobial agents can be obtained via combined mechanisms. For instance, gentamicin resistance, although it does not rely on the antibiotic modification, it is executed thru altering the membrane potential and efflux, as well as 16S rRNA methylation (Waglechner and Wright 2017).

Inhibition of bacterial efflux pumps

Bacterial drug efflux pumps can efflux a large number of structurally unrelated drugs and have a significant role in the development of antimicrobial resistance in bacteria (Lubelski et al. 2007). Notably, Wang et al. (2014) and Lechner et al. (2008b) showed that biochanin A (20), along with its metabolite genistein (22) are potentiators of the antibacterial activities of norfloxacin and berberine in wild-type $S$. aureus and M. smegmatis, respectively. However, the inhibitory effect of those flavonoids on NorA MDR efflux pump (MFS family) was said to be rather moderate. Mild inhibitory effects were also reported for the sarothrin (18) from Alkanna orientalis, which inhibited the growth of M. smegmatis and S. aureus and possessed
NorA efflux pump inhibitory activity. Although the sarothrin alone is a weak antimicrobial agent, it could increase the activity of other antimicrobial compounds by blocking the bacterial efflux pumps (Bame et al. 2013). Furthermore, Fujita et al. (2005) restored the effectiveness of tetracycline against MRSA, by baicalein (11)-mediated inhibition of tetracycline efflux pump $(\operatorname{Tet}(\mathrm{K}))$. However, baicalein inhibited the transport of tetracycline in E. coli KAM32, which lacks the AcrAB pump. This latter observation suggests that baicalein inhibits some other extrusion pump(s) for tetracycline (Fujita et al. 2005). EGCG (42) also inhibited Tet(K) pumps in staphylococci, presumably by inhibiting the expression of Tet proteins (Roccaro et al. 2004).

In contrast to Gram-positive bacteria, Gram-negative bacteria are resistant to wide range of antibiotics, mainly due to the low permeability of their cell membrane. The main mechanism attributed to their resistance consists of MexAB-OprM and AcrAB-TolC efflux pumps as well as low porin expression (Breidenstein et al. 2011). Daidzein (21), an isoflavone, showed a very slight modulatory effect on $M$. smegmatis as an efflux pump inhibitor (Lechner et al. 2008b). However, molecular docking calculations and in vitro assays point it as an inhibitor of the MexABOprM and AcrAB-TolC tripartite efflux pumps existing in P. aeruginosa and E. coli (Aparna et al. 2014). Daidzein potentiated the efficacy of carbenicillin and levofloxacin antibiotics against both $E$. coli and $P$. aeruginosa. Furthermore, authors suggested that daidzein possibly circumvents the efflux resistance mechanism. The molecular dynamics studies performed by Suriyanarayanan and Sarojini Santhosh (2015) reported that quercetin (32) could bind to $M$. tuberculosis $\mathrm{Mmr}$ and E. coli EmrE efflux pumps, suggesting that it may downregulate the drug efflux and thus play a role of non-antibiotic adjuvant. A study by Dey et al. (2015) examined the antimicrobial activity of EGCG (42) and quercetin against drugresistant $M$. tuberculosis and $\beta$-lactamase producing $K$. pneumoniae and demonstrated the antimicrobial effects of both flavonoids. The results of Kurinčič et al. (2012) demonstrated that EGCG shows antibacterial activity and enhances antibiotic effects against clinical isolates of $P$. aeruginosa, and EGCG was proposed to act as an inhibitor of the efflux pump MexAB-OprM (Kurinčič et al. 2012). Similarly, EGCG, by impairing CmeDEF drug efflux systems, partially reversed the 
drug resistance of Campylobacter spp, (Kurinčič et al. 2012). Moreover, Christena et al. (2015) showed the role of efflux pumps in quorum sensing, cell-to-cell signaling, and biofilm formation.

Altogether, these reports suggest that flavonoids act rather as efflux pumps potentiators than inhibitors, and the mechanistic relationship between efflux pumps and biofilm formation requires further studies. The need for further studies is highlighted by the fact that efflux pumps make antibiotics ineffective, and the combination therapy along with the existing flavonoid inhibitors could solve this problem.

\section{Antimicrobial action vs ROS production}

It must be accepted that the mammalian innate immune system has evolved with sophisticated mechanisms to recognize and kill bacteria. These processes are mediated mainly by the phagocytosis mechanism, by which macrophages and neutrophils engulf bacterial cells to kill them by an "oxidative burst" produced by the NADPH oxidase, a main source for the generation of ROS in activated neutrophils and macrophages (Nunes et al. 2013).

A lot of studies have showed that the bactericidal antibiotics such as $\beta$-lactams, aminoglycosides, and fluoroquinolones induced oxidative stress, regardless of their specific targets, and participated in the ROSantibiotic bacteria killing [reviewed by Dwyer et al. (2014) and Vatansever et al. (2013)]. On the other hand, several other reports failed to show the link between ROS and antibiotic-mediated killing [reviewed by Van Acker and Coenye (2017)]. These inconsistent data may have resulted from the presence of ROS, which are generated through the hyperactivation of normal cell metabolism, as well as the related difficulty or even the impossibility to completely separate the effects of decreased ROS levels and ROS production as a consequence of the action of antibiotics (Dwyer et al. 2014; Van Acker and Coenye 2017). Flavonoids are considered as efficient ROS scavengers; however, the flavonoid concentration in human plasma and most tissues is too low to effectively reduce ROS (Brunetti et al. 2013). Furthermore, flavonoid ROS scavenger usage should be carefully considered, since low ROS concentrations are, on the contrary, beneficial for bacteria and can induce resistance. Thus, the function of flavonoids as an antimicrobial potentiator should rather be associated with the regulation of the activities of different proteins and molecular processes, and there is need for further studies, especially regarding their synergistic action.

Combined action of flavonoids and antibiotics

As already mentioned above, one of the suggested approaches for improving the antibiotic efficiency against bacteria involves the use of flavonoids as potentiators (Brynildsen et al. 2013). Moreover, flavonoids are used by cells for their protection against the harmful effects of ROS (Baldim et al. 2017; Brunetti et al. 2013; Pietta 2000; Prochazkova et al. 2011). Notably, Brynildsen et al. (2013) proposed to increase the antibiotic efficacy not by impairing the organism's ROS defense systems by adjuvants, such as flavonoids, but by amplifying the endogenous ROS production, which should compromise its ability to cope with an oxidative attack from the antibiotic. Kohanski et al. (2007) demonstrated that quinolones, $\beta$-lactams, and aminoglycosides stimulated hydroxyl radical formation via the Fenton reaction. Additionally, both the iron chelator and the hydroxyl radical quencher, which could be flavonoids, attenuate killing by bactericidal drugs, which suggest that hydroxyl radicals contribute to bactericidal antibiotic-mediated cell death. Furthermore, uptake of aminoglycoside antibiotics (AGs: gentamycin, amikacin, neomycin, streptomycin, spectinomycin, and tobramycin) is driven by the proton motive force (Taber et al. 1987), which is abolished when ROS concentrations are increased over wild-type levels (Ezraty et al. 2013; Farha and Brown 2013). Flavonoids like other iron chelators, protect against AGs by blocking AGs uptake via the impairment of $\mathrm{Fe}-\mathrm{S}$ cluster synthesis resulting in the impendence of the PMF (Ezraty et al. 2013).

The most common mechanism of AG resistance is the chemical modification by bacterial aminoglycoside-modifying enzymes (AMEs), acetyltransferases (AACs), nucleotidyltranferases (ANTs), or phosphotransferases (APHs) (Ramirez and Tolmasky 2010). Unfortunately, only few flavonoids were reported as inhibitor of these enzymes. The quercetin (32) was proposed as an APH inhibitor (Daigle et al. 1999; Shakya et al. 2011) and was shown to occupy the ATP binding site and to interact with the enzyme APH( $\left(2^{\prime \prime}\right)$-IVa through a series of hydrogen bonds. 
Moreover, apigenin (10) although did not affect $\operatorname{APH}\left(2^{\prime \prime}\right)-\mathrm{IVa}$, it was able to inhibit the closely related enzyme $\operatorname{APH}\left(2^{\prime \prime}\right)-$ IIa. Furthermore, metal cations $\left(\mathrm{Mg}^{2+}, \mathrm{Cr}^{3+}, \mathrm{Cr}^{6+}, \mathrm{Mn}^{2+}, \mathrm{Co}^{2+}, \mathrm{Ni}^{2+}, \mathrm{Cu}^{2+}, \mathrm{Zn}^{2+}\right.$, $\mathrm{Cd}^{2+}$, and $\mathrm{Au}^{3+}$ ) have been demonstrated to inhibit the AG acetyltransferase activity and to increase the efficacy of AGs in resistant strains (Li et al. 2015) Therefore, flavonoids as chelators could be used as a potential inhibitors of AMEs. However, such flavonoid application requires future research.

It should be considered, that combined use of antibiotics with flavonoids can lead to some negative effects. For example, isoquercetin (33) showed antagonism with aminoglycoside antibiotics such as neomycin, kanamycin, gentamicin, and amikacin when tested with E. coli 27 strain. However, quercetin did not affect the antibacterial activity of the aminoglycoside antibiotics. Moreover, both isoquercetin and quercetin (32) did not affect the action of aminoglycosides against a multiresistant strain of $S$. aureus (Veras et al. 2011).

\section{Testing antimicrobial activities and reasons for discrepancies in results}

Antimicrobial flavonoids are often described by the minimum inhibitory concentration (MIC), which is being their minimum concentration that causes visible inhibition of bacterial growth. MIC assessment is usually the first step of evaluation of new antimicrobials and it is determined in agar dilution or broth dilution assays (O'Neill and Chopra 2004). Plant extracts with MIC $\leq 100 \mu \mathrm{g} / \mathrm{mL}$ and purified compounds with $\mathrm{MIC} \leq 10 \mu \mathrm{g} / \mathrm{mL}$ are considered promising (Rios and Recio 2005). However, MIC parameter describes the bacteriostatic activity of the given compound only, same as Kirby-Bauer's agar diffusion test, which is also commonly used in the antimicrobial susceptibility testing (Ahmed et al. 2016; Awouafack et al. 2011; Tohma et al. 2016). However, with the increasing number of immunocompromised patients, it is important to develop a bactericidal drug, rather than just a bacteriostatic (Corti et al. 2009). Bactericidal activity is determined by the minimum bactericidal concentration (MBC) in time-kill assays. MBC and MIC parameters complement each other and MBC below the four times MIC value suggests the bactericidal action of a tested compound (French 2006). However, bactericidal studies depend on determining the Colony-Forming Units (CFU) number, while some flavonoids have been reported to induce the formation of multicellular aggregates. Thus, decrease in CFU numbers may result rather from the cell aggregation, than the bactericidal action of a tested compound. Since MBC studies of flavonoids are often unreliable, other assays must be used to ensure the lack of cell aggregation. Microscopic study-supported time-kill assays suggested by Cushnie et al. (2007) can be a solution to this problem.

Furthermore, many other factors may affect the results of antimicrobial in vitro studies, either it is the MIC, MBC studies or it is the Kirby-Bauer's antibiotic test. The most important variables include the sensitivity of strains, antimicrobial potential of a studied compound, the type of medium and the optical density of the inoculum (CLSI 2017). Clinical and Laboratory Standards Institute (CLSI) is one of the organizations that standardized many of these variables (CLSI 2017). For example, Müller-Hinton broth/agar is accepted as a standard growing medium for antimicrobial susceptibility testing, while the cell density of the inoculum for broth microdilution assay is typically at $5 \times 10^{5}$ (Wiegand et al. 2008). However, not all research teams follow CLSI guidelines, or even any guidelines at all. Moreover, there are limitations to each antimicrobial assay, for example, a flavonoid with poor agar diffusion abilities will yield weak results in agar diffusion test, despite its possibly good antimicrobial activity (Zheng et al. 1996). Furthermore, the solvent used for the preparation may influence the extract contents and affect the antimicrobial activity. Crude methanolic plant extracts typically have the highest concentration and highest number of flavonoids, and thereby the strongest antimicrobial activity (Dar et al. 2016). However, sometimes the pure compounds are isolated, which are usually hydrophobic and may precipitate in wrong solvents, e.g., water (Lof et al. 2011). This will lead to their reduced contact with the bacterial cells and thus decreased activity. Notably, some flavonoids have been known to form salts in alkaline solvents that can also influence their biological activities (Cushnie et al. 2003). Dimethyl sulfoxide (DMSO) that is typically used to dissolve isolated flavonoids offers good polyphenol solubility; however, the DMSO may also 
affect results by interacting with bacterial membranes (Mi et al. 2016).

\section{The most potent antimicrobial flavonoids}

In Table 1, we have summarized antimicrobial flavonoids with the MIC value below $10 \mu \mathrm{g} / \mathrm{mL}$. We chose the MIC value as a determinant, because it is the most commonly used characteristic of novel antimicrobials, including flavonoids. MBC values (if tested) are also presented in the Table 1 . Given the possibility of cell aggregation during MBC studies, as well as other potential reasons for results discrepancies, these data must be interpreted with caution. In majority of studies cited in Table 1, mechanisms of antibacterial action of tested flavonoids have not been elucidated. Mechanism of action and structure-activity relationship studies are usually conducted by research teams of different specialty, compared to those who report novel antimicrobial agents. It is understandable, since those areas of studies require different approach and expertise. It does, however, create a knowledge gap, where a lot of compounds are known for their antimicrobial activity, but little detail is known about mechanism of action of every one of them. Some of the compounds present in the Table 1 had been studied for their mechanism of action in different studies and have been described above.

\section{Examples of synergy and additive effect between flavonoids and antibiotics}

Recently, there has been a growing interest in uncovering novel antibiotic adjuvants through systematic approaches. Notably, the ability of plant metabolites to enhance the activity of antibiotics has been widely reported (Sana et al. 2015). These compounds that have potential activity against pathogenic bacteria are variably been termed modulating, resistance modifying, or reversal adjuvants. In this review, we provide examples of synergy between antibiotics and flavonoids. Most of the researchers propose flavonoids to be resistance modifying agents (RMAs). The mechanisms of RMA action may include inhibition of efflux pumps or antibioticdegrading enzymes and membrane permeabilization (Abreu et al. 2012). Interaction of two antimicrobial compounds is typically described by the fractional inhibitory concentration index (FICI) (Wang et al. 2014)

$$
\begin{aligned}
\text { FICI }= & \frac{\text { MIC }(\text { antibiotic alone })}{\text { MIC }(\text { antibiotic combined with compound })} \\
& +\frac{\text { MIC }(\text { compound alone })}{\text { MIC }(\text { compound combined with antibiotic })}
\end{aligned}
$$

Staphylococcus aureus with many resistant strains is one of the most dangerous pathogens nowadays (Lindsay 2013). Thus, there is an understandable desire to find agents that would enhance the available anti-staphylococcal drugs, and studies of most research teams are focused on the synergy of flavonoids and antibiotics against resistant $S$. aureus strains. Reports of synergy and additive effects of flavonoids and antibiotics are summarized in Table 2. Although the involvement of flavonoids in the bacterial growth control is extensively studied, their complexation with antibiotics remains poorly understood.

\section{Concluding remarks}

Recently, CDC estimated that one in five pathogens from hospital-acquired infections represents multidrug-resistant strain (MDR) (Weiner et al. 2016), while there is no progress in the development of new classes of antibiotics. Hence, there is a serious need for finding new antimicrobial agents or at least substances that would enhance the effectiveness of current drugs (Abreu et al. 2012). Notably, many flavonoids show strong antimicrobial effects and/or synergy with "conventional" antibiotics. There are also reports of flavonoids inhibiting bacterial virulence factors, such as hemolysis activity of $S$. aureus (Qiu et al. 2010).

Importantly, most of the flavonoids are considered nontoxic because of their ubiquity in all sorts of plantderived foods and beverages. Few toxicity studies support that notion. Dzoyem et al. (2013) conducted experiments on silkworm larvae, which supported low or no toxicity of tested flavonoids. Single-dose toxicity studies performed on lab rats also failed to determine methanolic extract of flavonoids as toxic (Kuete et al. 2007). Moreover, Ames test showed no mutagenic effect of the selected flavonoids (Bagla et al. 2014). Daily intake of flavonoids is estimated at 
Table 1 Strongest antimicrobial flavonoids reported in recent years (EGCG-epigallocatechin gallate; MRSA—methicillinresistant Staphylococcus aureus; MSSA-methicillin-sensitive
S. aureus; NT-not tested; PPSA-penicillinase-producing $S$. aureus; VISA — vancomycin-intermediate S. aureus; VREvancomycin-resistant Enterococci)

\begin{tabular}{|c|c|c|c|}
\hline Flavonoid & $\mathrm{MIC} / \mathrm{MBC}(\mu \mathrm{g} / \mathrm{mL})$ & Strain & References \\
\hline Flavone & $1.95 / 3.9$ & P. vulgaris, $P$. mirabilis & Basile et al. (2010) \\
\hline Isolupalbigenin & $1.56-3.13 / 6.25-25$ & MRSA & Sato et al. (2006) \\
\hline Galangin & $\begin{array}{l}0.89-14.16 / \\
1.38-23.44\end{array}$ & $\begin{array}{l}\text { MSSA, MRSA, } \\
\text { Enterococcus spp., } \\
\text { P. aeruginosa }\end{array}$ & Pepeljnjak and Kosalec (2004) \\
\hline Rutin & $8 / 16$ & K. pneumoniae & Djouossi et al. (2015) \\
\hline Rhamnoisorobin & $1-2 / \mathrm{NT}$ & $\begin{array}{l}\text { S. aureus, } P \text {. aeruginosa, } \\
\text { S. typhi }\end{array}$ & Tatsimo et al. (2012) \\
\hline 2-hydroxylupinifolinol & $2.3-4.7 / \mathrm{NT}$ & $\begin{array}{l}\text { MSSA, MRSA, } \\
\text { S. pyrogenes, B. cereus }\end{array}$ & Thongnest et al. (2013) \\
\hline $3^{\prime}$-O-methyldiplacol & $2-4 / \mathrm{NT}$ & $\begin{array}{l}\text { B. cereus, E. faecalis, } \\
\text { L. monocytogenes, } \\
\text { S. aureus, S. epidermidis }\end{array}$ & Smejkal et al. (2008) \\
\hline 2,8-diprenyleriodictyol & $0.5-4 / \mathrm{NT}$ & MSSA, MRSA & Dzoyem et al. (2013) \\
\hline Diplacone & $2-16 / 4.9-39.2$ & MRSA & Navratilova et al. (2016) \\
\hline Hesperetin & $4-32 / \mathrm{NT}$ & S. aureus & Lopes et al. (2017) \\
\hline Naringenin & $\geq 2.8 / \mathrm{NT}$ & M. tuberculosis & Chen et al. (2010) \\
\hline Pinocembrin & $3.5 / \mathrm{NT}$ & M. tuberculosis & Chou et al. (2011) \\
\hline Sepicanin A & $2.9 / 2.9$ & MRSA & Radwan et al. (2009) \\
\hline Dihydrokaempferol & $6.25 / 12.5-25$ & VRE, S. aureus & Tajuddeen et al. (2014) \\
\hline Bartericin A & $0.31-0.61 / \mathrm{NT}$ & $\begin{array}{l}\text { C. freundii, S. dysenteriae, } \\
\text { B. cereus, S. aureus, } \\
\text { S. faecalis (among others) }\end{array}$ & Kuete et al. (2007) \\
\hline Isobavachalcone & $0.3-0.6 / 0.6-1.2$ & $\begin{array}{l}\text { S. faecalis, S. aureus, } \\
\text { E. aerogenes, E. cloacae } \\
\text { (among others) }\end{array}$ & Mbaveng et al. (2008) \\
\hline Panduratin A & $1-2 / 4-8$ & E. faecalis, E. faecium & Rukayadi et al. (2010) \\
\hline Phloretin & $1 / \mathrm{NT}$ & S. aureus & Lopes et al. (2017) \\
\hline Licochalcone A & $2-8 / \mathrm{NT}$ & MSSA, MRSA & Qiu et al. (2010) \\
\hline
\end{tabular}

100-1000 mg/day, depending on the diet (Aherne and O'Brien 2002). In general, no adverse effects have been associated with high dietary intakes of flavonoids from plant-based food. Flavonoid-rich foods and beverages include tea, red wine, fruit skins, citrus fruits, berry fruits, and honey (Kumar and Pandey 2013). Those foods are typically attributed to many health benefits. The lack of toxicity and natural occurrence makes flavonoids possibly good food preservatives. They can be a viable candidate for replacing synthetic preservatives that are disliked by the consumers (Wu et al. 2013). The lack of adverse effects may be explained by the relatively low bioavailability and rapid metabolism that leads to elimination of most of the flavonoids (Harwood et al. 2007; Ottaviani et al. 2015). To date, the importance of the safe use of flavonoid supplements in pregnancy and lactation has not been well established (Hendler and Rorvik 2009; Mills et al. 2013). Moreover, the use of green tea extracts was directly associated with abnormally high levels of liver enzymes (Dostal et al. 2015; Sarma et al. 2008). Obviously, further toxicity studies are needed before releasing any food or medicine containing high amounts of flavonoids. 
Table 2 Examples of synergy and additives effect between antibiotics and flavonoids (FICI-fractional inhibitory concentration index; EGCG_epigallocatechin gallate; MSSA—methicillin-sensitive Staphylococcus aureus; MRSA-methicillin-resistant S. aureus; PPSA — penicillinase-producing S. aureus, VISA—vancomycin-intermediate S. aureus)

\begin{tabular}{|c|c|c|c|c|}
\hline Flavonoid & Antibiotic & $\mathrm{FICI}^{\mathrm{a}}$ & Strain & References \\
\hline Flavone & $\begin{array}{l}\text { Vancomycin } \\
\text { Oxacillin }\end{array}$ & $\begin{array}{l}0.096 \\
0.126\end{array}$ & VISA ATCC 700699 & Bakar et al. (2012) \\
\hline Apigenin & $\begin{array}{l}\text { Ampicillin, } \\
\text { Ceftriaxone }\end{array}$ & $0.18-0.47$ & MRSA strains & $\begin{array}{l}\text { Akilandeswari and Ruckmani } \\
\text { (2016) }\end{array}$ \\
\hline Baicalein & Tetracycline & $0.06-0.12$ & MRSA strains & Fujita et al. (2005) \\
\hline Baicalein & $\begin{array}{l}\text { Penicillin } \\
\text { Amoxicillin }\end{array}$ & $\begin{array}{l}0.14-0.25 \\
0.14-0.38\end{array}$ & PPSA strains & Qian et al. (2015) \\
\hline Baicalein & Cloxacillin & $<0.02$ & S. aureus DMST 20651 & Eumkeb et al. (2010) \\
\hline Diosmetin & $\begin{array}{l}\text { Streptomycin } \\
\text { Ciprofloxacin }\end{array}$ & $\begin{array}{l}0.39 \\
0.09\end{array}$ & $\begin{array}{l}\text { S. aureus } 1199 \mathrm{~B}, \mathrm{RN} 4220 \\
\text { S. aureus EMRSA-15 }\end{array}$ & Wang et al. (2014) \\
\hline Luteolin & $\begin{array}{l}\text { Ampicillin, } \\
\text { Cephradine, } \\
\text { Ceftriaxone, } \\
\text { Imipenem, } \\
\text { Methicillin }\end{array}$ & $0.82-0.9$ & MRSA ATCC 43300 & Usman Amin et al. (2016) \\
\hline $\begin{array}{l}\text { Luteolin } \\
\text { Genistein }\end{array}$ & Ceftazidime & $\begin{array}{l}0.37 \\
0.27\end{array}$ & $\begin{array}{l}\text { S. pyogenes DMST } \\
30653-30655\end{array}$ & Siriwong et al. (2015) \\
\hline Genistein & $\begin{array}{l}\text { Norfloxacin } \\
\text { Ciprofloxacin }\end{array}$ & $\begin{array}{l}0.38 \\
0.09\end{array}$ & $\begin{array}{l}\text { S. aureus 1199B, } \\
\text { RN4220, } \\
\text { S. aureus EMRSA-15 }\end{array}$ & Wang et al. (2014) \\
\hline Galangin & Cloxacillin & $<0.02$ & S. aureus DMST 20651 & Eumkeb et al. (2010) \\
\hline Morin & Ampicillin & $\begin{array}{l}0.31 \\
0.75\end{array}$ & $\begin{array}{l}\text { MRSA ATCC } 3359 \\
\text { MRSA DPS-1 }\end{array}$ & Mun et al. (2015) \\
\hline $\begin{array}{l}\text { Myricetin } \\
\text { Galangin } \\
\text { Kaempferide } \\
\text { Kaempferide-3-O- } \\
\text { glucoside }\end{array}$ & $\begin{array}{l}\text { Isoniazid } \\
\text { Amoxicillin }\end{array}$ & $\begin{aligned} & 0.2 \\
< & 0.09\end{aligned}$ & $\begin{array}{l}\text { M. smegmatis } \mathrm{mc}^{2} 155 \\
\text { E. coli }(\mathrm{AREC})\end{array}$ & $\begin{array}{l}\text { Lechner et al. (2008a) } \\
\text { Eumkeb et al. (2012) }\end{array}$ \\
\hline Quercetin & Cloxacillin & $<0.02$ & S. aureus DMST 20651 & Eumkeb et al. (2010) \\
\hline $\begin{array}{l}\text { Quercetin } \\
\text { Quercetin + luteolin } \\
\text { Rutin + morin }\end{array}$ & $\begin{array}{l}\text { Ceftriaxone, } \\
\text { Imipenem, } \\
\text { Methicillin }\end{array}$ & $\begin{array}{l}0.66-0.84 \\
0.45-0.65 \\
0.8-0.9\end{array}$ & $\begin{array}{l}\text { MRSA ATCC } 43300, \\
\text { MRSA Clinical Isolates }\end{array}$ & Usman Amin et al. (2016) \\
\hline EGCG & $\begin{array}{l}\text { Tetracycline } \\
\text { Oxacillin }\end{array}$ & $\begin{array}{l}0.375 \\
0.5\end{array}$ & MRSA6975, MRSA3202 & Navratilova et al. (2016) \\
\hline $\begin{array}{l}\text { Synthetic } \\
\text { 3-arylideneflavanones }\end{array}$ & $\begin{array}{l}\text { Vancomycin } \\
\text { Oxacillin }\end{array}$ & $\begin{array}{c}0.97 \\
0.01-0.58\end{array}$ & $\begin{array}{l}\text { E. faecium } \\
\text { S. aureus A3 }\end{array}$ & Budzynska et al. (2011) \\
\hline
\end{tabular}

a'Synergy' was defined where the FICI was less than or equal to 0.5 ; whilst 'additive' effects were observed when the FICI was greater than 0.5 and less than or equal to 1.0; greater than 1 and less than 2 as indifferent; Antagonistic effects were observed when the FICI was greater than 2.0

Furthermore, to increase the specificity and safety of flavonoids more focus on their mechanisms of action and a structure-activity relationship is required.
Considering the hydrophobic nature of flavonoids, few questions are raised regarding their in vivo activity, like "how to achieve and sustain their high 
blood serum concentration?" Their structural modifications or use of drug carriers may be essential to modulate their infiltration into the bloodstream. On the other hand, getting to know flavonoid metabolism in mammalian cells may be helpful in preventing their rapid catabolism. Thus, determining if flavonoids are effective antimicrobials at in vivo environment remains crucial. Finally, flavonoids maintain their biological activity, thanks to a finely regulated transport and accumulation system that allow entrance into different subcellular compartments. Nevertheless, a comprehensive view of the phenomenon has not yet been proposed and is still under investigation.

\section{Compliance with ethical standards}

Conflict of interest The authors have declared that there is no conflict of interest.

Open Access This article is distributed under the terms of the Creative Commons Attribution 4.0 International License (http:// creativecommons.org/licenses/by/4.0/), which permits unrestricted use, distribution, and reproduction in any medium, provided you give appropriate credit to the original author(s) and the source, provide a link to the Creative Commons license, and indicate if changes were made.

\section{References}

Abdullahi UF, Igwenagu E, Mu'azu A, Aliyu S, Umar MI (2016) Intrigues of biofilm: a perspective in veterinary medicine. Veterinary World 9:12-18

Abreu AC, McBain AJ, Simoes M (2012) Plants as sources of new antimicrobials and resistance-modifying agents. Nat Prod Rep 29:1007-1021

Aherne SA, O'Brien NM (2002) Dietary flavonols: chemistry, food content, and metabolism. Nutrition 18:75-81

Ahmed SI, Hayat MQ, Tahir M, Mansoor Q, Ismail M, Keck K, Bates RB (2016) Pharmacologically active flavonoids from the anticancer, antioxidant and antimicrobial extracts of Cassia angustifolia Vahl. BMC Complement Altern Med 16:460

Akilandeswari K, Ruckmani K (2016) Synergistic antibacterial effect of apigenin with beta-lactam antibiotics and modulation of bacterial resistance by a possible membrane effect against methicillin resistant Staphylococcus aureus. Cell Mol Biol (Noisy-le-grand) 62:74-82

Aldred KJ, Kerns RJ, Osheroff N (2014) Mechanism of quinolone action and resistance. Biochemistry 53:1565-1574

Anderson ER, Lovin ME, Richter SJ, Lacey EP (2013) Multiple Plantago species (Plantaginaceae) modify floral reflectance and color in response to thermal change. Am J Bot 100:2485-2493

Aparna V, Dineshkumar K, Mohanalakshmi N, Velmurugan D, Hopper W (2014) Identification of natural compound inhibitors for multidrug efflux pumps of Escherichia coli and Pseudomonas aeruginosa using in silico highthroughput virtual screening and in vitro validation. PLoS ONE 9:e101840

Appelbaum PC (2012) 2012 and beyond: potential for the start of a second pre-antibiotic era? J Antimicrob Chemother 67:2062-2068

Arora A, Byrem TM, Nair MG, Strasburg GM (2000) Modulation of liposomal membrane fluidity by flavonoids and isoflavonoids. Arch Biochem Biophys 373:102-109

Awolola GV, Koorbanally NA, Chenia H, Shode FO, Baijnath H (2014) Antibacterial and anti-biofilm activity of flavonoids and triterpenes isolated from the extracts of Ficus Sansibarica warb. Subsp. Sansibarica (Moraceae) extracts. Afr J Tradit Complement Altern Med 11:124-131

Awouafack MD, Spiteller P, Lamshoft M, Kusari S, Ivanova B, Tane P, Spiteller M (2011) Antimicrobial isopropenyl-dihydrofuranoisoflavones from Crotalaria lachnophora. J Nat Prod 74:272-278

Bagla VP, McGaw LJ, Elgorashi EE, Eloff JN (2014) Antimicrobial activity, toxicity and selectivity index of two biflavonoids and a flavone isolated from Podocarpus henkelii (Podocarpaceae) leaves. BMC Complement Altern Med 14:383

Bakar NS, Zin NM, Basri DF (2012) Synergy of flavone with vancomycin and oxacillin against vancomycin-intermediate Staphyloccus aureus. Pak J Pharm Sci 25:633-638

Baldim JL, de Alcantara BGV, Domingos ODS, Soares MG, Caldas IS, Novaes RD, Oliveira TB, Lago JHG, ChagasPaula DA (2017) The correlation between chemical structures and antioxidant, prooxidant, and antitrypanosomatid properties of flavonoids. Oxid Med Cell Longev 2017:3789856

Bame JR, Graf TN, Junio HA, Bussey RO, Jarmusch SA, ElElimat T, Falkinham JO, Oberlies NH, Cech RA, Cech NB (2013) Sarothrin from Alkanna orientalis is an antimicrobial agent and efflux pump inhibitor. Planta Med 79:327-329

Barboza TJS, Ferreira AF, Ignácio ACPR, Albarello N (2016) Cytotoxic, antibacterial and antibiofilm activities of aqueous extracts of leaves and flavonoids occurring in Kalanchoe pinnata (Lam.) Pers. J Med Plants Res 10:763-770

Basile A, Conte B, Rigano D, Senatore F, Sorbo S (2010) Antibacterial and antifungal properties of acetonic extract of Feijoa sellowiana fruits and its effect on Helicobacter pylori growth. J Med Food 13:189-195

Baugh S, Ekanayaka AS, Piddock LJ, Webber MA (2012) Loss of or inhibition of all multidrug resistance efflux pumps of Salmonella enterica serovar Typhimurium results in impaired ability to form a biofilm. J Antimicrob Chemother 67:2409-2417

Bay DC, Rommens KL, Turner RJ (2008) Small multidrug resistance proteins: a multidrug transporter family that continues to grow. Biochim Biophys Acta 1778:1814-1838

Beck S, Stengel J (2016) Mass spectrometric imaging of flavonoid glycosides and biflavonoids in Ginkgo biloba L. Phytochemistry 130:201-206

Bhosle A, Chandra N (2016) Structural analysis of dihydrofolate reductases enables rationalization of antifolate binding 
affinities and suggests repurposing possibilities. FEBS J 283:1139-1167

Borges A, Abreu A, Malheiro J, Saavedra M, Simões M (2013) Biofilm prevention and control by dietary phytochemicals. In: Mendez-Vilas A (ed) Microbial pathogens and strategies for combating them: science, technology and education. Formatex Research Cente, Badajoz, pp 32-41

Bouayed J, Bohn T (2010) Exogenous antioxidants-doubleedged swords in cellular redox state: health beneficial effects at physiologic doses versus deleterious effects at high doses. Oxid Med Cell Longev 3:228-237

Boumendjel A (2003) Aurones: a subclass of flavones with promising biological potential. Curr Med Chem 10:2621-2630

Bravo A, Anacona JR (2001) Metal complexes of the flavonoid quercetin: antibacterial properties. Transition Met Chem 26:20-23

Breidenstein EB, de la Fuente-Nunez C, Hancock RE (2011) Pseudomonas aeruginosa: all roads lead to resistance. Trends Microbiol 19:419-426

Brown AK, Papaemmanouil A, Bhowruth V, Bhatt A, Dover LG, Besra GS (2007) Flavonoid inhibitors as novel antimycobacterial agents targeting Rv0636, a putative dehydratase enzyme involved in Mycobacterium tuberculosis fatty acid synthase II. Microbiology 153:3314-3322

Brunetti C, Di Ferdinando M, Fini A, Pollastri S, Tattini M (2013) Flavonoids as antioxidants and developmental regulators: relative significance in plants and humans. Int J Mol Sci 14:3540-3555

Brynildsen MP, Winkler JA, Spina CS, MacDonald IC, Collins JJ (2013) Potentiating antibacterial activity by predictably enhancing endogenous microbial ROS production. Nat Biotechnol 31:160-165

Budzynska A, Rozalski M, Karolczak W, Wieckowska-Szakiel M, Sadowska B, Rozalska B (2011) Synthetic 3-arylideneflavanones as inhibitors of the initial stages of biofilm formation by Staphylococcus aureus and Enterococcus faecalis. Z Naturforsch C 66:104-114

Bush K (2013) The ABCD's of beta-lactamase nomenclature. J Infect Chemother 19:549-559

Bush K, Fisher JF (2011) Epidemiological expansion, structural studies, and clinical challenges of new beta-lactamases from gram-negative bacteria. Annu Rev Microbiol 65:455-478

Campbell EA, Korzheva N, Mustaev A, Murakami K, Nair S, Goldfarb A, Darst SA (2001) Structural mechanism for rifampicin inhibition of bacterial rna polymerase. Cell 104:901-912

Chabot S, Bel-Rhlid R, Chenevert R, Piche Y (1992) Hyphal growth promotion in vitro of the VA mycorrhizal fungus, Gigaspora margarita Becker and Hall, by the activity of structurally specific flavonoid compounds under $\mathrm{CO}_{2}$-enriched conditions. New Phytol 122:461-467

Chen LW, Cheng MJ, Peng CF, Chen IS (2010) Secondary metabolites and antimycobacterial activities from the roots of Ficus nervosa. Chem Biodivers 7:1814-1821

Chen H, Wu W, Ni M, Liu Y, Zhang J, Xia F, He W, Wang Q, Wang Z, Cao B, Wang H (2013) Linezolid-resistant clinical isolates of enterococci and Staphylococcus cohnii from a multicentre study in China: molecular epidemiology and resistance mechanisms. Int $\mathrm{J}$ Antimicrob Agents 42:317-321

Chen L, Teng H, Xie Z, Cao H, Cheang WS, Skalicka-Woniak K, Georgiev MI, Xiao J (2018) Modifications of dietary flavonoids towards improved bioactivity: an update on structure-activity relationship. Crit Rev Food Sci Nutr 58:513-527

Chinnam N, Dadi PK, Sabri SA, Ahmad M, Kabir MA, Ahmad Z (2010) Dietary bioflavonoids inhibit Escherichia coli ATP synthase in a differential manner. Int J Biol Macromol 46:478-486

Cho M-H, Lee S-W (2015) Phenolic phytoalexins in rice: biological functions and biosynthesis. Int $\mathrm{J}$ Mol Sci 16:29120-29133

Choi O, Yahiro K, Morinaga N, Miyazaki M, Noda M (2007) Inhibitory effects of various plant polyphenols on the toxicity of Staphylococcal $\boldsymbol{\alpha}$-toxin. Microb Pathog 42:215-224

Chou TH, Chen JJ, Peng CF, Cheng MJ, Chen IS (2011) New flavanones from the leaves of Cryptocarya chinensis and their antituberculosis activity. Chem Biodivers 8:2015-2024

Christena LR, Subramaniam S, Vidhyalakshmi M, Mahadevan V, Sivasubramanian A, Nagarajan S (2015) Dual role of pinostrobin-a flavonoid nutraceutical as an efflux pump inhibitor and antibiofilm agent to mitigate food borne pathogens. RSC Adv 5:61881-61887

CLSI (2017) Performance standards for antimicrobial susceptibility testing, vol. CLSI supplement M100. Clinical and Laboratory Standards Institute, Wayne, PA, USA, p 224

Corti M, Palmero D, Eiguchi K (2009) Respiratory infections in immunocompromised patients. Curr Opin Pulm Med 15:209-217

Costerton JW, Lewandowski Z, Caldwell DE, Korber DR, Lappin-Scott HM (1995) Microbial biofilms. Annu Rev Microbiol 49:711-745

Cowan MM (1999) Plant products as antimicrobial agents. Clin Microbiol Rev 12:564-582

Croft AC, D'Antoni AV, Terzulli SL (2007) Update on the antibacterial resistance crisis. Med Sci Monit 13:RA103RA118

Cushnie TP, Lamb AJ (2005) Antimicrobial activity of flavonoids. Int J Antimicrob Agents 26:343-356

Cushnie TP, Lamb AJ (2011) Recent advances in understanding the antibacterial properties of flavonoids. Int J Antimicrob Agents 38:99-107

Cushnie TP, Hamilton VE, Lamb AJ (2003) Assessment of the antibacterial activity of selected flavonoids and consideration of discrepancies between previous reports. Microbiol Res 158:281-289

Cushnie TP, Hamilton VE, Chapman DG, Taylor PW, Lamb AJ (2007) Aggregation of Staphylococcus aureus following treatment with the antibacterial flavonol galangin. J Appl Microbiol 103:1562-1567

Cushnie TP, Taylor PW, Nagaoka Y, Uesato S, Hara Y, Lamb $\mathrm{AJ}$ (2008) Investigation of the antibacterial activity of 3-Ooctanoyl-(-)-epicatechin. J Appl Microbiol 105:1461-1469

Daigle DM, McKay GA, Thompson PR, Wright GD (1999) Aminoglycoside antibiotic phosphotransferases are also serine protein kinases. Chem Biol 6:11-18 
Dar KB, Bhat AH, Amin S, Anees S, Masood A, Zargar MI, Ganie SA (2016) Efficacy of aqueous and methanolic extracts of Rheum spiciformis against pathogenic bacterial and fungal strains. J Clin Diagn Res 10:BC18-BC22

Delehanty JB, Johnson BJ, Hickey TE, Pons T, Ligler FS (2007) Binding and neutralization of lipopolysaccharides by plant proanthocyanidins. J Nat Prod 70:1718-1724

Dey D, Ray R, Hazra B (2015) Antimicrobial activity of pomegranate fruit constituents against drug-resistant $M y$ cobacterium tuberculosis and beta-lactamase producing Klebsiella pneumoniae. Pharm Biol 53:1474-1480

Djouossi MG, Tamokou JD, Ngnokam D, Kuiate JR, Tapondjou LA, Harakat D, Voutquenne-Nazabadioko L (2015) Antimicrobial and antioxidant flavonoids from the leaves of Oncoba spinosa Forssk (Salicaceae). BMC Complement Altern Med 15:134

Domenech-Sanchez A, Martinez-Martinez L, Hernandez-Alles S, del Carmen Conejo M, Pascual A, Tomas JM, Alberti S, Benedi VJ (2003) Role of Klebsiella pneumoniae OmpK35 porin in antimicrobial resistance. Antimicrob Agents Chemother 47:3332-3335

Donhofer A, Franckenberg S, Wickles S, Berninghausen O, Beckmann R, Wilson DN (2012) Structural basis for TetMmediated tetracycline resistance. Proc Natl Acad Sci U S A 109:16900-16905

Dostal AM, Samavat H, Bedell S, Torkelson C, Wang R, Swenson K, Le C, Wu AH, Ursin G, Yuan JM, Kurzer MS (2015) The safety of green tea extract supplementation in postmenopausal women at risk for breast cancer: results of the Minnesota Green Tea trial. Food Chem Toxicol 83:26-35

Dwyer DJ, Belenky PA, Yang JH, MacDonald IC, Martell JD, Takahashi N, Chan CTY, Lobritz MA, Braff D, Schwarz EG, Ye JD, Pati M, Vercruysse M, Ralifo PS, Allison KR, Khalil AS, Ting AY, Walker GC, Collins JJ (2014) Antibiotics induce redox-related physiological alterations as part of their lethality. Proc Natl Acad Sci USA 111:E2100-E2109

Dzoyem JP, Hamamoto H, Ngameni B, Ngadjui BT, Sekimizu K (2013) Antimicrobial action mechanism of flavonoids from Dorstenia species. Drug Discov Ther 7:66-72

Edziri H, Mastouri M, Mahjoub MA, Mighri Z, Mahjoub A, Verschaeve L (2012) Antibacterial, antifungal and cytotoxic activities of two flavonoids from Retama raetam flowers. Molecules 17:7284-7293

El-Adawi H (2012) Inhibitory effect of grape seed extract (GSE) on cariogenic bacteria. J Med Plants Res 6:4883-4891

Elmasri WA, Zhu R, Peng W, Al-Hariri M, Kobeissy F, Tran P, Hamood AN, Hegazy MF, Pare PW, Mechref Y (2017) Multitargeted flavonoid inhibition of the pathogenic bacterium Staphylococcus aureus: a proteomic characterization. J Proteome Res 16:2579-2586

Eumkeb G, Sakdarat S, Siriwong S (2010) Reversing beta-lactam antibiotic resistance of Staphylococcus aureus with galangin from Alpinia officinarum Hance and synergism with ceftazidime. Phytomedicine 18:40-45

Eumkeb G, Siriwong S, Phitaktim S, Rojtinnakorn N, Sakdarat S (2012) Synergistic activity and mode of action of flavonoids isolated from smaller galangal and amoxicillin combinations against amoxicillin-resistant Escherichia coli. J Appl Microbiol 112:55-64
Ezraty B, Vergnes A, Banzhaf M, Duverger Y, Huguenot A, Brochado AR, Su S-Y, Espinosa L, Loiseau L, Py B, Typas A, Barras F (2013) Fe-S cluster biosynthesis controls uptake of aminoglycosides in a ROS-less death pathway. Science 340:1583-1587

Falcone Ferreyra ML, Rius SP, Casati P (2012) Flavonoids: biosynthesis, biological functions, and biotechnological applications. Front Plant Sci 3:222

Fang Y, Lu Y, Zang X, Wu T, Qi X, Pan S, Xu X (2016) 3DQSAR and docking studies of flavonoids as potent Escherichia coli inhibitors. Sci Rep 6:23634

Farha MA, Brown ED (2013) Discovery of antibiotic adjuvants. Nat Biotechnol 31:120-122

Fathima A, Rao JR (2016) Selective toxicity of Catechin-a natural flavonoid towards bacteria. Appl Microbiol Biotechnol 100:6395-6402

Fernández L, Hancock REW (2012) Adaptive and mutational resistance: role of porins and efflux pumps in drug resistance. Clin Microbiol Rev 25:661-681

French GL (2006) Bactericidal agents in the treatment of MRSA infections-the potential role of daptomycin. J Antimicrob Chemother 58:1107-1117

Fujita M, Shiota S, Kuroda T, Hatano T, Yoshida T, Mizushima $\mathrm{T}$, Tsuchiya T (2005) Remarkable synergies between baicalein and tetracycline, and baicalein and $\beta$-lactams against methicillin-resistant Staphylococcus aureus. Microbiol Immunol 49:391-396

Gardete S, Tomasz A (2014) Mechanisms of vancomycin resistance in Staphylococcus aureus. J Clin Invest 124:2836-2840

Gatto MT, Falcocchio S, Grippa E, Mazzanti G, Battinelli L, Nicolosi G, Lambusta D, Saso L (2002) Antimicrobial and anti-lipase activity of quercetin and its C2-C16 3-O-acylesters. Bioorg Med Chem 10:269-272

Girish KS, Kemparaju K (2007) The magic glue hyaluronan and its eraser hyaluronidase: a biological overview. Life Sci 80:1921-1943

Gledhill JR, Montgomery MG, Leslie AG, Walker JE (2007) Mechanism of inhibition of bovine F1-ATPase by resveratrol and related polyphenols. Proc Natl Acad Sci USA 104:13632-13637

Griep MA, Blood S, Larson MA, Koepsell SA, Hinrichs SH (2007) Myricetin inhibits Escherichia coli DnaB helicase but not primase. Bioorg Med Chem 15:7203-7208

Haraguchi H, Tanimoto K, Tamura Y, Mizutani K, Kinoshita T (1998) Mode of antibacterial action of retrochalcones from Glycyrrhiza inflata. Phytochemistry 48:125-129

Harborne JB, Baxter H (1999) The handbook of natural flavonoids. Wiley, New York

Harborne JB, Williams CA (2000) Advances in flavonoid research since 1992. Phytochemistry 55:481-504

Hartmann M, Berditsch M, Hawecker J, Ardakani MF, Gerthsen D, Ulrich AS (2010) Damage of the bacterial cell envelope by antimicrobial peptides gramicidin $\mathrm{S}$ and PGLa as revealed by transmission and scanning electron microscopy. Antimicrob Agents Chemother 54:3132-3142

Harwood M, Danielewska-Nikiel B, Borzelleca JF, Flamm GW, Williams GM, Lines TC (2007) A critical review of the data related to the safety of quercetin and lack of evidence of in vivo toxicity, including lack of genotoxic/carcinogenic properties. Food Chem Toxicol 45:2179-2205 
Hassan KA, Jackson SM, Penesyan A, Patching SG, Tetu SG, Eijkelkamp BA, Brown MH, Henderson PJF, Paulsen IT (2013) Transcriptomic and biochemical analyses identify a family of chlorhexidine efflux proteins. Proc Natl Acad Sci USA 110:20254-20259

Hatier JHB, Gould KS (2009) Anthocyanin function in vegetative organs. In: Gould KS, Davies K, Winefield C (eds) Anthocyanins. Springer, New York, pp 1-19

Havsteen B (1983) Flavonoids, a class of natural products of high pharmacological potency. Biochem Pharmacol 32:1141-1148

Havsteen BH (2002) The biochemistry and medical significance of the flavonoids. Pharmacol Ther 96:67-202

Hayet E, Maha M, Samia A, Mata M, Gros P, Raida H, Ali MM, Mohamed AS, Gutmann L, Mighri Z, Mahjoub A (2008) Antimicrobial, antioxidant, and antiviral activities of $R e$ tama raetam (Forssk.) Webb flowers growing in Tunisia. World J Microbiol Biotechnol 24:2933-2940

Hendler SS, Rorvik DR (2009) PDR for nutritional supplements. Montvale, Medical Economics Data, U.S

Hertel W, Peschel G, Ozegowski J-H, Müller P-J (2006) Inhibitory effects of triterpenes and flavonoids on the enzymatic activity of hyaluronic acid-splitting enzymes. Arch Pharm 339:313-318

Hiramatsu K (2001) Vancomycin-resistant Staphylococcus aureus: a new model of antibiotic resistance. Lancet Infect Dis 1:147-155

Hobman JL, Crossman LC (2015) Bacterial antimicrobial metal ion resistance. J Med Microbiol 64:471-497

Ikigai H, Nakae T, Hara Y, Shimamura T (1993) Bactericidal catechins damage the lipid bilayer. Biochim Biophys Acta 1147:132-136

International Union of Pure and Applied Chemistry (1993) A Guide to IUPAC nomenclature of organic compounds: recommendations 1993. Blackwell Scientific Publications, Oxford

Iwashina T (2003) Flavonoid function and activity to plants and other organisms. Biol Sci Space 17:24-44

Jamal M, Ahmad W, Andleeb S, Jalil F, Imran M, Nawaz MA, Hussain T, Ali M, Rafiq M, Kamil MA (2018) Bacterial biofilm and associated infections. J Chin Med Assoc $81: 7-11$

Jeong KW, Lee JY, Kang DI, Lee JU, Shin SY, Kim Y (2009) Screening of flavonoids as candidate antibiotics against Enterococcus faecalis. J Nat Prod 72:719-724

Kariu T, Nakao R, Ikeda T, Nakashima K, Potempa J, Imamura $\mathrm{T}$ (2016) Inhibition of gingipains and Porphyromonas gingivalis growth and biofilm formation by prenyl flavonoids. J Periodontal Res 52:89-96

Karlíčková J, Macáková K, Říha M, Pinheiro LMT, Filipský T, Horňasová V, Hrdina R, Mladěnka P (2015) Isoflavones reduce copper with minimal impact on iron in vitro. Oxid Med Cell Longev 2015:11

Kasprzak MM, Erxleben A, Ochocki J (2015) Properties and applications of flavonoid metal complexes. RSC Adv 5:45853-45877

Kohanski MA, Dwyer DJ, Hayete B, Lawrence CA, Collins JJ (2007) A common mechanism of cellular death induced by bactericidal antibiotics. Cell 130:797-810

Kon K, Rai M (2016) Antibiotic resistance: mechanisms and new antimicrobial approaches. Academic Press, USA
Kopacz M, Woznicka E, Gruszecka J (2005) Antibacterial activity of morin and its complexes with $\mathrm{La}(\mathrm{III}), \mathrm{Gd}(\mathrm{III})$ and Lu(III) ions. Acta Pol Pharm 62:65-67

Kragh KN, Hutchison JB, Melaugh G, Rodesney C, Roberts AEL, Irie Y, Jensen PØ, Diggle SP, Allen RJ, Gordon V, Bjarnsholt T (2016) Role of multicellular aggregates in biofilm formation. mBio 7:e00237-00216

Kuete V, Simo IK, Ngameni B, Bigoga JD, Watchueng J, Kapguep RN, Etoa FX, Tchaleu BN, Beng VP (2007) Antimicrobial activity of the methanolic extract, fractions and four flavonoids from the twigs of Dorstenia angusticornis Engl. (Moraceae). J Ethnopharmacol 112:271-277

Kumar S, Pandey AK (2013) Chemistry and biological activities of flavonoids: an overview. Sci World J 2013:162750

Kurinčič M, Klančnik A, Smole Možina S (2012) Effects of efflux pump inhibitors on erythromycin, ciprofloxacin, and tetracycline resistance in Campylobacter spp. isolates. Microb Drug Resist 18:492-501

Lambert PA, Hammond SM (1973) Potassium fluxes, first indications of membrane damage in micro-organisms. Biochem Biophys Res Commun 54:796-799

Lechner D, Gibbons S, Bucar F (2008a) Modulation of isoniazid susceptibility by flavonoids in Mycobacterium. Phytochem Lett 1:71-75

Lechner D, Gibbons S, Bucar F (2008b) Plant phenolic compounds as ethidium bromide efflux inhibitors in $M y$ cobacterium smegmatis. J Antimicrob Chemother 62:345-348

Leclercq R, Courvalin P (2002) Resistance to macrolides and related antibiotics in Streptococcus pneumoniae. Antimicrob Agents Chemother 46:2727-2734

Lee P, Tan KS (2015) Effects of epigallocatechin gallate against Enterococcus faecalis biofilm and virulence. Arch Oral Biol 60:393-399

Lee JH, Regmi SC, Kim JA, Cho MH, Yun H, Lee CS, Lee J (2011) Apple flavonoid phloretin inhibits Escherichia coli O157:H7 biofilm formation and ameliorates colon inflammation in rats. Infect Immun 79:4819-4827

Li BH, Tian WX (2004) Inhibitory effects of flavonoids on animal fatty acid synthase. J Biochem 135:85-91

Li B-H, Zhang R, Du Y-T, Sun Y-H, Tian W-X (2006) Inactivation mechanism of the $\beta$-ketoacyl-[acyl carrier protein] reductase of bacterial type-II fatty acid synthase by epigallocatechin gallate. Biochem Cell Biol 84:755-762

Li W, Atkinson GC, Thakor NS, Allas U, Lu CC, Chan KY, Tenson T, Schulten K, Wilson KS, Hauryliuk V, Frank J (2013) Mechanism of tetracycline resistance by ribosomal protection protein $\mathrm{Tet}(\mathrm{O})$. Nat Commun 4:1477

Li Y, Green KD, Johnson BR, Garneau-Tsodikova S (2015) Inhibition of aminoglycoside acetyltransferase resistance enzymes by metal salts. Antimicrob Agents Chemother 59:4148-4156

Lindsay JA (2013) Hospital-associated MRSA and antibiotic resistance-what have we learned from genomics? Int J Med Microbiol 303:318-323

Lof D, Schillen K, Nilsson L (2011) Flavonoids: precipitation kinetics and interaction with surfactant micelles. J Food Sci 76:N35-N39

Lopes LAA, dos Santos Rodrigues JB, Magnani M, de Souza EL, de Siqueira-Júnior JP (2017) Inhibitory effects of flavonoids on biofilm formation by Staphylococcus aureus 
that overexpresses efflux protein genes. Microb Pathog 107:193-197

Lu M (2016) Structures of multidrug and toxic compound extrusion transporters and their mechanistic implications. Channels (Austin) 10:88-100

Lubelski J, Konings WN, Driessen AJ (2007) Distribution and physiology of $\mathrm{ABC}$-type transporters contributing to multidrug resistance in bacteria. Microbiol Mol Biol Rev 71:463-476

Matijašević D, Pantić M, Rašković B, Pavlović V, Duvnjak D, Sknepnek A, Nikšić M (2016) The antibacterial activity of coriolus versicolor methanol extract and its effect on ultrastructural changes of Staphylococcus aureus and Salmonella enteritidis. Front Microbiol 7:1226

Matsumoto Y, Kaihatsu K, Nishino K, Ogawa M, Kato N, Yamaguchi A (2012) Antibacterial and antifungal activities of new acylated derivatives of epigallocatechin gallate. Front Microbiol 3:53

Mbaveng AT, Ngameni B, Kuete V, Simo IK, Ambassa P, Roy R, Bezabih M, Etoa FX, Ngadjui BT, Abegaz BM, Meyer JJ, Lall N, Beng VP (2008) Antimicrobial activity of the crude extracts and five flavonoids from the twigs of Dorstenia barteri (Moraceae). J Ethnopharmacol 116:483-489

McGuinness WA, Malachowa N, DeLeo FR (2017) Vancomycin resistance in Staphylococcus aureus. Yale J Biol Med 90:269-281

Mi H, Wang D, Xue Y, Zhang Z, Niu J, Hong Y, Drlica K, Zhao X (2016) Dimethyl sulfoxide protects Escherichia coli from rapid antimicrobial-mediated killing. Antimicrob Agents Chemother 60:5054-5058

Mills E, Dugoua JJ, Perri D, Koren G (2013) Herbal medicines in pregnancy and lactation: an evidence-based approach. CRC Press, London

Mirzoeva OK, Grishanin RN, Calder PC (1997) Antimicrobial action of propolis and some of its components: the effects on growth, membrane potential and motility of bacteria. Microbiol Res 152:239-246

Mishra AK, Mishra A, Kehri H, Sharma B, Pandey AK (2009) Inhibitory activity of Indian spice plant Cinnamomum zeylanicum extracts against Alternaria solani and Curvularia lunata, the pathogenic dematiaceous moulds. Ann Clin Microbiol Antimicrob 8:9

Mori A, Nishino C, Enoki N, Tawata S (1987) Antibacterial activity and mode of action of plant flavonoids against Proteus vulgaris and Staphylococcus aureus. Phytochemistry 26:2231-2234

Mun S-H, Lee Y-S, Han S-H, Lee S-W, Cha S-W, Kim S-B, Seo Y-S, Kong R, Kang D-H, Shin D-W, Kang O-H, Kwon D-Y (2015) In vitro potential effect of morin in the combination with $\beta$-lactam antibiotics against methicillin-resistant Staphylococcus aureus. Foodborne Pathog Dis 12:545-550

Munita JM, Arias CA (2016) Mechanisms of antibiotic resistance. Microbiol Spectr 4(2):1-2

Narbona E, Buide ML, Casimiro-Soriguer I, Del Valle JC (2014) Polimorfismos de color floral: causas e implicaciones evolutivas. Ecosistemas 23:36-47

Navarro-Martinez MD, Navarro-Peran E, Cabezas-Herrera J, Ruiz-Gomez J, Garcia-Canovas F, Rodriguez-Lopez JN (2005) Antifolate activity of epigallocatechin gallate against Stenotrophomonas maltophilia. Antimicrob Agents Chemother 49:2914-2920

Navratilova A, Nesuta O, Vancatova I, Cizek A, Varela MR, Lopez-Aban J, Villa-Pulgarin JA, Mollinedo F, Muro A, Zemlickova H, Kadlecova D, Smejkal K (2016) C-geranylated flavonoids from Paulownia tomentosa fruits with antimicrobial potential and synergistic activity with antibiotics. Pharm Biol 54:1398-1407

Newman DJ (2008) Natural products as leads to potential drugs: an old process or the new hope for drug discovery? J Med Chem 51:2589-2599

Nicotra AB, Atkin OK, Bonser SP, Davidson AM, Finnegan EJ, Mathesius U, Poot P, Purugganan MD, Richards CL, Valladares F, van Kleunen M (2010) Plant phenotypic plasticity in a changing climate. Trends Plant Sci 15:684-692

Nikaido H, Takatsuka Y (2009) Mechanisms of RND multidrug efflux pumps. Biochim Biophys Acta 1794:769-781

Nunes P, Demaurex N, Dinauer MC (2013) Regulation of the NADPH oxidase and associated ion fluxes during phagocytosis. Traffic 14:1118-1131

Nyila MA, Leonard CM, Hussein AA, Lall N (2012) Activity of South African medicinal plants against Listeria monocytogenes biofilms, and isolation of active compounds from Acacia karroo. S Afr J Bot 78:220-227

Ohemeng KA, Schwender CF, Fu KP, Barrett JF (1993) DNA gyrase inhibitory and antibacterial activity of some flavones. Bioorg Med Chem Lett 3:225-230

Olczak T, Simpson W, Liu X, Genco CA (2005) Iron and heme utilization in Porphyromonas gingivalis. FEMS Microbiol Rev 29:119-144

Ollila F, Halling K, Vuorela P, Vuorela H, Slotte JP (2002) Characterization of flavonoid-biomembrane interactions. Arch Biochem Biophys 399:103-108

O'Neill AJ, Chopra I (2004) Preclinical evaluation of novel antibacterial agents by microbiological and molecular techniques. Expert Opin Investig Drugs 13:1045-1063

Ono K, Nakane H, Fukushima M, Chermann J-C, BarrÉ-Sinoussi F (1990) Differential inhibitory effects of various flavonoids on the activities of reverse transcriptase and cellular DNA and RNA polymerases. Eur J Biochem 190:469-476

Oteiza PI, Erlejman AG, Verstraeten SV, Keen CL, Fraga CG (2005) Flavonoid-membrane Interactions: a protective role of flavonoids at the membrane surface? Clin Dev Immunol 12:19-25

Ottaviani JI, Balz M, Kimball J, Ensunsa JL, Fong R, Momma TY, Kwik-Uribe C, Schroeter H, Keen CL (2015) Safety and efficacy of cocoa flavanol intake in healthy adults: a randomized, controlled, double-masked trial. Am J Clin Nutr 102:1425-1435

Ouyang J, Sun F, Feng W, Sun Y, Qiu X, Xiong L, Liu Y, Chen $Y$ (2016) Quercetin is an effective inhibitor of quorum sensing, biofilm formation and virulence factors in Pseudomonas aeruginosa. J Appl Microbiol 120:966-974

Paczkowski JE, Mukherjee S, McCready AR, Cong JP, Aquino CJ, Kim H, Henke BR, Smith CD, Bassler BL (2017) Flavonoids suppress Pseudomonas aeruginosa virulence through allosteric inhibition of quorum-sensing receptors. J Biol Chem 292:4064-4076 
Pages JM, James CE, Winterhalter M (2008) The porin and the permeating antibiotic: a selective diffusion barrier in Gram-negative bacteria. Nat Rev Microbiol 6:893-903

Pandey AK, Kumar S (2013) Perspective on plant products as antimicrobials agents: a review. Pharmacologia 4:469-480

Panhwar QK, Memon S (2011) Synthesis and evaluation of antioxidant and antibacterial properties of morin complexes. J Coord Chem 64:2117-2129

Pao SS, Paulsen IT, Saier MH Jr (1998) Major facilitator superfamily. Microbiol Mol Biol Rev 62:1-34

Pepeljnjak S, Kosalec I (2004) Galangin expresses bactericidal activity against multiple-resistant bacteria: MRSA, Enterococcus spp. and Pseudomonas aeruginosa. FEMS Microbiol Lett 240:111-116

Perumal Samy R, Gopalakrishnakone P (2010) Therapeutic potential of plants as anti-microbials for drug discovery. Evid Based Complement Alternat Med 7:283-294

Piasecka A, Jedrzejczak-Rey N, Bednarek P (2015) Secondary metabolites in plant innate immunity: conserved function of divergent chemicals. New Phytol 206:948-964

Piddock LJ (2006) Clinically relevant chromosomally encoded multidrug resistance efflux pumps in bacteria. Clin Microbiol Rev 19:382-402

Pietta P-G (2000) Flavonoids as antioxidants. J Nat Prod 63:1035-1042

Pisteli L, Giorgi I (2012) Antimicrobial action of flavonoids. In: Patra AK (ed) Dietary phytochemicals and microbes. Springer, Netherlands, pp 33-61

Plaper A, Golob M, Hafner I, Oblak M, Solmajer T, Jerala R (2003) Characterization of quercetin binding site on DNA gyrase. Biochem Biophys Res Commun 306:530-536

Poole K (2005) Efflux-mediated antimicrobial resistance. J Antimicrob Chemother 56:20-51

Prasad VGNV, Krishna BV, Swamy PL, Rao TS, Rao GS (2014) Antibacterial synergy between quercetin and polyphenolic acids against bacterial pathogens of fish. Asian Pac J Trop Dis 4:S326-S329

Prochazkova D, Bousova I, Wilhelmova N (2011) Antioxidant and prooxidant properties of flavonoids. Fitoterapia 82:513-523

Qian M, Tang S, Wu C, Wang Y, He T, Chen T, Xiao X (2015) Synergy between baicalein and penicillins against penicillinase-producing Staphylococcus aureus. Int J Med Microbiol 305:501-504

Qiu J, Jiang Y, Xia L, Xiang H, Feng H, Pu S, Huang N, Yu L, Deng X (2010) Subinhibitory concentrations of licochalcone A decrease alpha-toxin production in both methicillin-sensitive and methicillin-resistant Staphylococcus aureus isolates. Lett Appl Microbiol 50:223-229

Radwan MM, Rodriguez-Guzman R, Manly SP, Jacob M, Ross SA (2009) Sepicanin A-a new geranyl flavanone from Artocarpus sepicanus with activity against methicillin-resistant Staphylococcus aureus (MRSA). Phytochem Lett 2:141-143

Raju A, Degani MS, Khambete MP, Ray MK, Rajan MG (2015) Antifolate activity of plant polyphenols against Mycobacterium tuberculosis. Phytother Res 29:1646-1651

Ramirez MS, Tolmasky ME (2010) Aminoglycoside modifying enzymes. Drug Resist Updat 13:151-171

Rasul A, Millimouno FM, Ali Eltayb W, Ali M, Li J, Li X (2013) Pinocembrin: a novel natural compound with versatile pharmacological and biological activities. Biomed Res Int 2013:379850

Rauter AP (2013) Nomenclature of flavonoids. International Union of Pure and Applied Chemistry

Ren J, Meng S, Lekka CHE, Kaxiras R (2008) Complexation of flavonoids with iron: structure and optical signatures. J Phys Chem B 112:1845-1850

Rendón MAA, Saldaña Z, Erdem AL, Monteiro-Neto V, Vázquez A, Kaper JB, Puente JL, Girón JA (2007) Commensal and pathogenic Escherichia coli use a common pilus adherence factor for epithelial cell colonization. Proc Natl Acad Sci USA 104:10637-10642

Reygaert WC (2014) The antimicrobial possibilities of green tea. Front Microbiol 5:434

Riha M, Karlickova J, Filipsky T, Macakova K, Rocha L, Bovicelli P, Silvestri IP, Saso L, Jahodar L, Hrdina R, Mladenka P (2014) In vitro evaluation of copper-chelating properties of flavonoids. RSC Adv 4:32628-32638

Rios JL, Recio MC (2005) Medicinal plants and antimicrobial activity. J Ethnopharmacol 100:80-84

Roccaro AS, Blanco AR, Giuliano F, Rusciano D, Enea V (2004) Epigallocatechin-gallate enhances the activity of tetracycline in Staphylococci by inhibiting its efflux from bacterial cells. Antimicrob Agents Chemother 48:1968-1973

Roy R, Tiwari M, Donelli G, Tiwari V (2017) Strategies for combating bacterial biofilms: a focus on anti-biofilm agents and their mechanisms of action. Virulence 9:522-554

Ruddock PS, Charland M, Ramirez S, López A, Neil Towers GH, Arnason JT, Liao M, Dillon J-AR (2011) Antimicrobial activity of flavonoids from Piper lanceaefolium and other colombian medicinal plants against antibiotic susceptible and resistant strains of Neisseria gonorrhoeae. Sex Transm Dis 38:82-88

Rukayadi Y, Han S, Yong D, Hwang JK (2010) In vitro antibacterial activity of panduratin A against enterococci clinical isolates. Biol Pharm Bull 33:1489-1493

Russo P, Del Bufalo A, Cesario A (2012) Flavonoids acting on DNA topoisomerases: recent advances and future perspectives in cancer therapy. Curr Med Chem 19:5287-5293

Saleem M, Nazir M, Ali MS, Hussain H, Lee YS, Riaz N, Jabbar A (2010) Antimicrobial natural products: an update on future antibiotic drug candidates. Nat Prod Rep 27:238-254

Samsonowicz M, Regulska E, Kalinowska M (2017) Hydroxyflavone metal complexes-molecular structure, antioxidant activity and biological effects. Chem Biol Interact 273:245-256

Sana M, Jameel H, Rahman M (2015) Miracle remedy: inhibition of bacterial efflux pumps by natural products. J Infect Dis Ther 3:1000213

Sanver D, Murray BS, Sadeghpour A, Rappolt M, Nelson AL (2016) Experimental modeling of flavonoid-biomembrane interactions. Langmuir 32:13234-13243

Sarma DN, Barrett ML, Chavez ML, Gardiner P, Ko R, Mahady GB, Marles RJ, Pellicore LS, Giancaspro GI, Low Dog T (2008) Safety of green tea extracts: a systematic review by the US Pharmacopeia. Drug Saf 31:469-484 
Sato M, Fujiwara S, Tsuchiya H, Fujii T, Iinuma M, Tosa H, Ohkawa Y (1996) Flavones with antibacterial activity against cariogenic bacteria. J Ethnopharmacol 54:171-176

Sato M, Tsuchiya H, Akagiri M, Takagi N, Iinuma M (1997) Growth inhibition of oral bacteria related to denture stomatitis by anti-candidal chalcones. Aust Dent $\mathrm{J}$ 42:343-346

Sato M, Tanaka H, Tani N, Nagayama M, Yamaguchi R (2006) Different antibacterial actions of isoflavones isolated from Erythrina poeppigiana against methicillin-resistant Staphylococcus aureus. Lett Appl Microbiol 43:243-248

Sawamura S, Sakane I, Satoh E, Ishii T, Shimizu Y, Nishimura M, Umehara K (2002) Isolation and determination of an antidote for botulinum neurotoxin from black tea extract. Folia Pharmacol Jap 120:116-118

Schiestl FP, Johnson SD (2013) Pollinator-mediated evolution of floral signals. Trends Ecol Evol 28:307-315

Schmidt TJ, Khalid SA, Romanha AJ, Alves TM, Biavatti MW, Brun R, Costa FBD, Castro SLD, Ferreira VF, Lacerda MVGD, Lago JHG, Leon LL, Lopes NP, Amorim RCDN, Niehues M, Ogungbe IV, Pohlit AM, Scotti MT, Setzer WN, Soeiro MDNC, Steindel M, Tempone AG (2012) The potential of secondary metabolites from plants as drugs or leads against protozoan neglected diseases-part II. Curr Med Chem 19:2176-2228

Schwarz S, Kehrenberg C, Doublet B, Cloeckaert A (2004) Molecular basis of bacterial resistance to chloramphenicol and florfenicol. FEMS Microbiol Rev 28:519-542

Senior AE, Nadanaciva S, Weber J (2002) The molecular mechanism of ATP synthesis by $\mathrm{F}_{1} \mathrm{~F}_{0}$-ATP synthase. Biochim Biophys Acta 1553:188-211

Shadrick WR, Ndjomou J, Kolli R, Mukherjee S, Hanson AM, Frick DN (2013) Discovering new medicines targeting helicases: challenges and recent progress. J Biomol Screen 18:761-781

Shah PM (2005) The need for new therapeutic agents: what is the pipeline? Clin Microbiol Infect 11(Suppl 3):36-42

Shah S, Stapleton PD, Taylor PW (2008) The polyphenol (-)epicatechin gallate disrupts the secretion of virulence-related proteins by Staphylococcus aureus. Lett Appl Microbiol 46:181-185

Shakya T, Stogios Peter J, Waglechner N, Evdokimova E, Ejim L, Blanchard Jan E, McArthur Andrew G, Savchenko A, Wright Gerard D (2011) A small molecule discrimination map of the antibiotic resistance kinome. Chem Biol 18:1591-1601

Singh SP, Konwarh R, Konwar BK, Karak N (2013) Molecular docking studies on analogues of quercetin with D-alanine:D-alanine ligase of Helicobacter pylori. Med Chem Res 22:2139-2150

Siriwong S, Thumanu K, Hengpratom T, Eumkeb G (2015) Synergy and mode of action of ceftazidime plus quercetin or luteolin on Streptococcus pyogenes. Evid Based Complement Alternat Med 2015:1-12

Sirk TW, Brown EF, Friedman M, Sum AK (2009) Molecular binding of catechins to biomembranes: relationship to biological activity. J Agric Food Chem 57:6720-6728

Smejkal K, Chudik S, Kloucek P, Marek R, Cvacka J, Urbanova M, Julinek O, Kokoska L, Slapetova T, Holubova P, Zima A, Dvorska M (2008) Antibacterial C-geranylflavonoids from Paulownia tomentosa fruits. J Nat Prod 71:706-709
Soromou LW, Zhang Y, Cui Y, Wei M, Chen N, Yang X, Huo M, Balde A, Guan S, Deng X, Wang D (2013) Subinhibitory concentrations of pinocembrin exert anti-Staphylococcus aureus activity by reducing alpha-toxin expression. J Appl Microbiol 115:41-49

Soto SM (2013) Role of efflux pumps in the antibiotic resistance of bacteria embedded in a biofilm. Virulence 4:223-229

Spina M, Cuccioloni M, Mozzicafreddo M, Montecchia F, Pucciarelli S, Eleuteri AM, Fioretti E, Angeletti M (2008) Mechanism of inhibition of wt-dihydrofolate reductase from E. coli by tea epigallocatechin-gallate. Proteins 72:240-251

Stapleton PD, Shah S, Hamilton-Miller JM, Hara Y, Nagaoka Y, Kumagai A, Uesato S, Taylor PW (2004) Anti-Staphylococcus aureus activity and oxacillin resistance modulating capacity of 3-O-acyl-catechins. Int J Antimicrob Agents 24:374-380

Stepanovic S, Antic N, Dakic I, Svabic-Vlahovic M (2003) In vitro antimicrobial activity of propolis and synergism between propolis and antimicrobial drugs. Microbiol Res 158:353-357

Sugita-Konishi Y, Hara-Kudo Y, Amano F, Okubo T, Aoi N, Iwaki M, Kumagai S (1999) Epigallocatechin gallate and gallocatechin gallate in green tea catechins inhibit extracellular release of vero toxin from enterohemorrhagic Escherichia coli O157:H7. Biochim Biophys Acta 1472:42-50

Suriyanarayanan B, Sarojini Santhosh R (2015) Docking analysis insights quercetin can be a non-antibiotic adjuvant by inhibiting Mmr drug efflux pump in Mycobacterium sp. and its homologue EmrE in Escherichia coli. J Biomol Struct Dyn 33:1819-1834

Suriyanarayanan B, Shanmugam K, Santhosh R (2013) Synthetic quercetin inhibits mycobacterial growth possibly by interacting with DNA gyrase. Rom Biotechnol Lett 18:1587-1593

Symeonidis A, Marangos M (2012) Iron and microbial growth. In: Priti DR (ed) Insight and control of infectious disease in global scenario. InTechOpen, London

Taber HW, Mueller JP, Miller PF, Arrow AS (1987) Bacterial uptake of aminoglycoside antibiotics. Microbiol Rev 51:439-457

Tajuddeen N, Sallau MS, Musa AM, Habila DJ, Yahaya SM (2014) Flavonoids with antimicrobial activity from the stem bark of Commiphora pedunculata (Kotschy \& Peyr.) Engl. Nat Prod Res 28:1915-1918

Tatsimo SJ, Tamokou Jde D, Havyarimana L, Csupor D, Forgo P, Hohmann J, Kuiate JR, Tane P (2012) Antimicrobial and antioxidant activity of kaempferol rhamnoside derivatives from Bryophyllum pinnatum. BMC Res Notes 5:158

Tereschuk ML, Riera MV, Castro GR, Abdala LR (1997) Antimicrobial activity of flavonoids from leaves of Tagetes minuta. J Ethnopharmacol 56:227-232

Thongnest S, Lhinhatrakool T, Wetprasit N, Sutthivaiyakit P, Sutthivaiyakit S (2013) Eriosema chinense: a rich source of antimicrobial and antioxidant flavonoids. Phytochemistry 96:353-359

Tofighi Z, Molazem M, Doostdar B, Taban P, Shahverdi AR, Samadi N, Yassa N (2015) Antimicrobial activities of three medicinal plants and investigation of flavonoids of 
Tripleurospermum disciforme. Iran $\mathrm{J}$ Pharm Res 14:225-231

Tohma H, Koksal E, Kilic O, Alan Y, Yilmaz MA, Gulcin I, Bursal E, Alwasel SH (2016) RP-HPLC/MS/MS analysis of the phenolic compounds, antioxidant and antimicrobial activities of Salvia L.Species. Antioxidants (Basel) 5:38

Tsuchiya H (2015) Membrane interactions of phytochemicals as their molecular mechanism applicable to the discovery of drug leads from plants. Molecules 20:18923-18966

Tsuchiya H, Inuma M (2000) Reduction of membrane fluidity by antibacterial sophoraflavanone $\mathrm{G}$ isolated from Sophora exigua. Phytomedicine 7:161-165

Ulanowska K, Tkaczyk A, Konopa G, Węgrzyn G (2006) Differential antibacterial activity of genistein arising from global inhibition of DNA, RNA and protein synthesis in some bacterial strains. Arch Microbiol 184:271-278

Ulrey RK, Barksdale SM, Zhou W, van Hoek ML (2014) Cranberry proanthocyanidins have anti-biofilm properties against Pseudomonas aeruginosa. BMC Complement Altern Med 14:499

Usman Amin M, Khurram M, Khan TA, Faidah HS, Ullah Shah Z, Ur Rahman S, Haseeb A, Ilyas M, Ullah N, Umar Khayam SM, Iriti M (2016) Effects of luteolin and quercetin in combination with some conventional antibiotics against methicillin-resistant Staphylococcus aureus. Int J Mol Sci 17:1947

Van Acker H, Coenye T (2017) The role of reactive oxygen species in antibiotic-mediated killing of bacteria. Trends Microbiol 25:456-466

van Miert AS (1994) The sulfonamide-diaminopyrimidine story. J Vet Pharmacol Ther 17:309-316

Vasconcelos MA, Arruda FVS, de Alencar DB, Saker-Sampaio S, Albuquerque MRJR, dos Santos HS, Bandeira PN, Pessoa ODL, Cavada BS, Henriques M, Pereira MO, Teixeira EH (2014) Antibacterial and antioxidant activities of derriobtusone a isolated from Lonchocarpus obtusus. Biomed Res Int 2014:9

Vatansever F, de Melo WCMA, Avci P, Vecchio D, Sadasivam M, Gupta A, Chandran R, Karimi M, Parizotto NA, Yin R, Tegos GP, Hamblin MR (2013) Antimicrobial strategies centered around reactive oxygen species-bactericidal antibiotics, photodynamic therapy, and beyond. FEMS Microbiol Rev 37:955-989

Veeresham C (2012) Natural products derived from plants as a source of drugs. J Adv Pharm Technol Res 3:200-201

Veras H, Santos I, Santos A, Matias E, Leite G, Souza H, Costa J, Coutinho H (2011) Comparative evaluation of antibiotic and antibiotic modifying activity of quercetin and isoquercetin in vitro. Curr Top Nutraceut Res 9:25-30

Verdrengh M, Collins LV, Bergin P, Tarkowski A (2004) Phytoestrogen genistein as an anti-staphylococcal agent. Microbes Infect 6:86-92

Vikram A, Jayaprakasha GK, Jesudhasan PR, Pillai SD, Patil BS (2010) Suppression of bacterial cell-cell signalling, biofilm formation and type III secretion system by citrus flavonoids. J Appl Microbiol 109:515-527

Waglechner N, Wright GD (2017) Antibiotic resistance: it's bad, but why isn't it worse? BMC Biol 15:84

Walker EH, Pacold ME, Perisic O, Stephens L, Hawkins PT, Wymann MP, Williams RL (2000) Structural determinants of phosphoinositide 3-kinase inhibition by wortmannin,
LY294002, quercetin, myricetin, and staurosporine. Mol Cell 6:909-919

Wang SX, Zhang FJ, Feng QP, Li YL (1992) Synthesis, characterization, and antibacterial activity of transition metal complexes with 5-hydroxy-7,4'-dimethoxyflavone. J Inorg Biochem 46:251-257

Wang SY, Sun ZL, Liu T, Gibbons S, Zhang WJ, Qing M (2014) Flavonoids from Sophora moorcroftiana and their synergistic antibacterial effects on MRSA. Phytother Res 28:1071-1076

Weiner LM, Webb AK, Limbago B, Dudeck MA, Patel J, Kallen AJ, Edwards JR, Sievert DM (2016) Antimicrobial-resistant pathogens associated with healthcare-associated infections: summary of data reported to the National Healthcare Safety Network at the Centers for Disease Control and Prevention, 2011-2014. Infect Control Hosp Epidemiol 37:1288-1301

Wiegand I, Hilpert K, Hancock RE (2008) Agar and broth dilution methods to determine the minimal inhibitory concentration (MIC) of antimicrobial substances. Nat Protoc 3:163-175

Wu D, Kong Y, Han C, Chen J, Hu L, Jiang H, Shen X (2008) DAlanine:D-alanine ligase as a new target for the flavonoids quercetin and apigenin. Int J Antimicrob Agents 32:421-426

Wu T, Zang X, He M, Pan S, Xu X (2013) Structure-activity relationship of flavonoids on their anti-Escherichia coli activity and inhibition of DNA gyrase. J Agric Food Chem 61:8185-8190

Xu H, Ziegelin G, Schroder W, Frank J, Ayora S, Alonso JC, Lanka E, Saenger W (2001) Flavones inhibit the hexameric replicative helicase RepA. Nucleic Acids Res 29:5058-5066

Xu X, Zhou XD, Wu CD (2011) The tea catechin epigallocatechin gallate suppresses cariogenic virulence factors of Streptococcus mutans. Antimicrob Agents Chemother 55:1229-1236

Xu X, Zhou XD, Wu CD (2012) Tea catechin epigallocatechin gallate inhibits Streptococcus mutans biofilm formation by suppressing gtf genes. Arch Oral Biol 57:678-683

Zhang YM, Rock CO (2004) Evaluation of epigallocatechin gallate and related plant polyphenols as inhibitors of the FabG and FabI reductases of bacterial type II fatty-acid synthase. J Biol Chem 279:30994-31001

Zhang F, Luo SY, Ye YB, Zhao WH, Sun XG, Wang ZQ, Li R, Sun YH, Tian WX, Zhang YX (2008a) The antibacterial efficacy of an aceraceous plant [Shantung maple (Acer truncatum Bunge)] may be related to inhibition of bacterial beta-oxoacyl-acyl carrier protein reductase (FabG). Biotechnol Appl Biochem 51:73-78

Zhang L, Kong Y, Wu D, Zhang H, Wu J, Chen J, Ding J, Hu L, Jiang H, Shen X (2008b) Three flavonoids targeting the beta-hydroxyacyl-acyl carrier protein dehydratase from Helicobacter pylori: crystal structure characterization with enzymatic inhibition assay. Protein Sci 17:1971-1978

Zhao W-H, Hu Z-Q, Okubo S, Hara Y, Shimamura T (2001) Mechanism of synergy between epigallocatechin gallate and $\beta$-Lactams against methicillin-resistant Staphylococcus aureus. Antimicrob Agents Chemother 45:1737-1742

Zheng WF, Tan RX, Yang L, Liu ZL (1996) Two flavones from Artemisia giraldii and their antimicrobial activity. Planta Med 62:160-162 